Southern Illinois University Edwardsville SPARK

SIUE Faculty Research, Scholarship, and Creative Activity

$5-2020$

\title{
Lexical complexities in the St. Louis dialect island
}

Larry LaFond

Southern Illinois University Edwardsville, llafond@siue.edu

Kenneth Moffett

kmoffet@siue.edu

Follow this and additional works at: https://spark.siue.edu/siue_fac

Part of the American Popular Culture Commons, English Language and Literature Commons, and the Modern Languages Commons

\section{Recommended Citation}

LaFond, Larry and Kenneth W. Moffett. "Lexical Complexities in the St. Louis Dialect Island." Forthcoming in American Speech.

This Article is brought to you for free and open access by SPARK. It has been accepted for inclusion in SIUE Faculty Research, Scholarship, and Creative Activity by an authorized administrator of SPARK. For more information, please contact magrase@siue.edu. 


\section{Lexical complexities in the St. Louis dialect island}

Larry LaFond, Professor

Department of English Language and Literature

Southern Illinois University Edwardsville

0219 Peck Hall, Box 1431

Edwardsville, Illinois 62026-1430

llafond@siue.edu

(618) 650-2144

and

Kenneth W. Moffett, Professor

Department of Political Science

Soutehrn Illinois University Edwardsville

3219 Peck Hall, Box 1453

Edwardsville, Illinois 62026-1453

kmoffet@siue.edu

(618) 650-2649 


\title{
Lexical complexities in the St. Louis dialect island
}

\begin{abstract}
:
The Greater St. Louis "dialect island" poses interesting problems for dialect documentation, partly because Greater St. Louis is a transitional area where many overlapping linguistic influences have left their mark, and also because is an area with new immigrant communities, racial divides, and an aging population.Using a sample from survey and interview data from 815 participants over a seven-year period, we examine lexical diversity in Greater St. Louis, comprising counties both in Missouri and Illinois. We discover that both age and place are robust indicators of lexical selection in Southern Illinois and St. Louis. Our findings provide a concurring rationale with phonologically-based studies that supports the existence of a unique dialect island in Greater St. Louis.
\end{abstract}

KEY TERMS: Midlands Dialect, Midwest, Metro East, St. Louis Corridor 
Hans Kurath, who observed in the 1930s that the Midland area of the Eastern United States was "highly complex," would today find the dialects of Illinois just as challenging. While many states contain an array of language regions, none contain as many as Illinois. According to the Dictionary of American Regional English (DARE), there are thirteen identified regions in this transitional state, permitting us to examine the influences of linguistic features common to the Midland, North Midland, South Midland, West Midland, Great Lakes, North, North Central, Inland North, Ohio Valley, Mississippi Valley, Upper Mississippi Valley, Lower Mississippi Valley, and Ohio-Mississippi Valleys.

Here, we examine lexical variation in Illinois, relative to the region in Southwestern Illinois known as the "Metro East," five counties of Southwestern Illinois which, together with the city of St. Louis and St. Louis County, form a larger entity: “Greater St. Louis.” Basing findings primarily on phonological features, some researchers have regarded Greater St. Louis as a dialect island. We furnish some lexical evidence that supports this claim, but use a novel approach for examining lexical data within this dialect area. The specific wording of lexical items investigated were based on the Harvard Dialect Study (HDS) (Vaux \& Golder, 2003). However, this study yields a new data collection focused on Greater St. Louis, and uses statistical models to analyze the data that have not commonly been used in dialect studies of this area.

The term "dialect island" extends the metaphor of the "language island" ("Sprachinsel,") first coined in 1847 to describe the relationship of a Slavonic community to the surrounding German-speaking areas in East Prussia (Mattheier \& Besch, 1985; Rosenberg, 2005; Riehl, 2010). While several dialect islands exist in Europe (see Auer, Hinskens, \& Kerswill, 2005), the phenomenon is found in numerous places worldwide, including in the United States. Riehl notes that early studies considered dialects spoken in language islands, “as 'pure', 'uncontaminated,' and 'homogeneous,'” however, later research found, "that most of the linguistic spaces under investigation not only used a mixture of different dialects, but also developed their own koiné..." (2010, p. 336). While not entirely homogeneous, linguistically or socially, and although they may differ in size and settlement history (Rosenberg, 2005), dialect islands all 
share the quality of being distinct from the areas that surround them. They are pockets, enclaves or colonies of dialect that have shared linguistic characteristics unlike those outside the island.

Greater St. Louis is one such island, and an examination of co-occurring phonological, lexical, and syntactic linguistic features confirms that this island, like many other islands, this one is not entirely homogeneous. We demonstrate that while both the Metro East and St. Louis proper form a language island whose characteristics differ from the rest of Illinois, there are fissures inside this island such that the two parts of the island are also distinguished from one another. Our data provide numerous instances of this finding. For example, respondents inside Greater St. Louis are less likely to use the term shopping cart than Illinois respondents outside the metropolitan area. However, there are also differences between the two halves of Greater St. Louis in regards to this term, with neither of the halves replicating responses found outside the metropolitan area.

We structure our analysis as follows: the first section discusses aspects of the settlement history of Illinois and situates Illinois and St. Louis with respect to earlier dialect research on these areas. Then, we present the methodology and research variables used for quantitative and qualitative analysis of survey and interview data. Two sections present the results, first from the quantitative analysis and then from the qualitative findings of collected interview data. Finally, we discuss the results, conclude, and elaborate the ways in which others can build on this research.

\section{SETTLEMENT HISTORY AND PREVIOUS STUDIES}

Illinois has an unusually high level of dialect mixture that may be linked to the settlement history of the state, through which successive waves of migration deposited linguistic resources. Wolfram \& Schilling (2016) report that prior to 1830 , the U.S. interior was affected by the direct westward expansion of settlers who brought their dialects with them. These dialects partly replicated the dialect maps of the Eastern states but with an intensification of dialect mixture and some leveling out of dialectal differences due to language contact, especially for speakers in "the ever-expanding Midland dialect region" (American English, p. 114). Migrations of Southern woodsmen into the Wabash, Sangamon and Mississippi River Valleys brought early southern dialectal influences into the region (Frazer, 1987), while 
physical geography played a key role, with northward movement along the rivers. Early settlement of Chicago brought movement from the north, with further extensions into the mining communities in Northwestern Illinois.

We have an incomplete picture of the exact nature of the dialects spoken in Illinois in late 1800s, but have some spoken clues coming from characterizations of literary dialect (see Fenno, 1983). Later influences came as a result of the National Highway that extended into Southern Illinois from the east, an antecedent to today's I-70, and movement to the south from Chicago to St. Louis along historic Route 66, the precursor of today's I-55, sometimes identified in dialect studies as the St. Louis Corridor. The resulting picture is a state with many layers of dialects, a region that " ....not only represents a crossroads of migration, a conduit from the East to the West, but also a transitional corridor between the two major cultural regions, the North and South" (Carver, 1989, p. 190).

Many have observed that Greater St. Louis, the St. Louis Corridor, and regions of Southern Illinois outside these areas pose interesting problems for dialect documentation (Callary, 1975; Carver, 1989; Friedman, 2015; Labov, 2007; Labov, Ash, \& Boberg, 1997, 2006; Murray, 1993, 2002; Frazer, 1978, 1987; Kurath, 1972; Marckwardt, 1957; Wolfram \& Schilling, 2016). One important piece of this complexity is found in Southwestern Illinois, where researchers have long observed that Greater St. Louis forms a dialect island within the broader Midland region (Frazer, 1987). Map 1 situates the dialect island within the United States, and Map 2 provides a visualization adapted from the Atlas of North American English (ANAE) (2006) showing that the surrounding Midlands dialect in Southern Illinois differs from the St. Louis area with a corridor that extends certain northern features southward. 


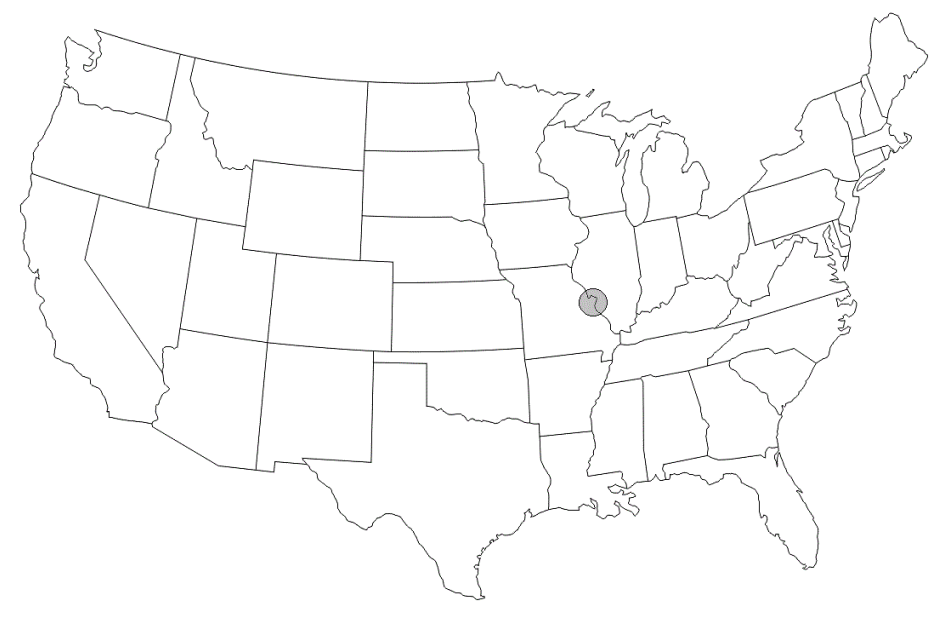

Map 1: Location of the St. Louis Dialect Island

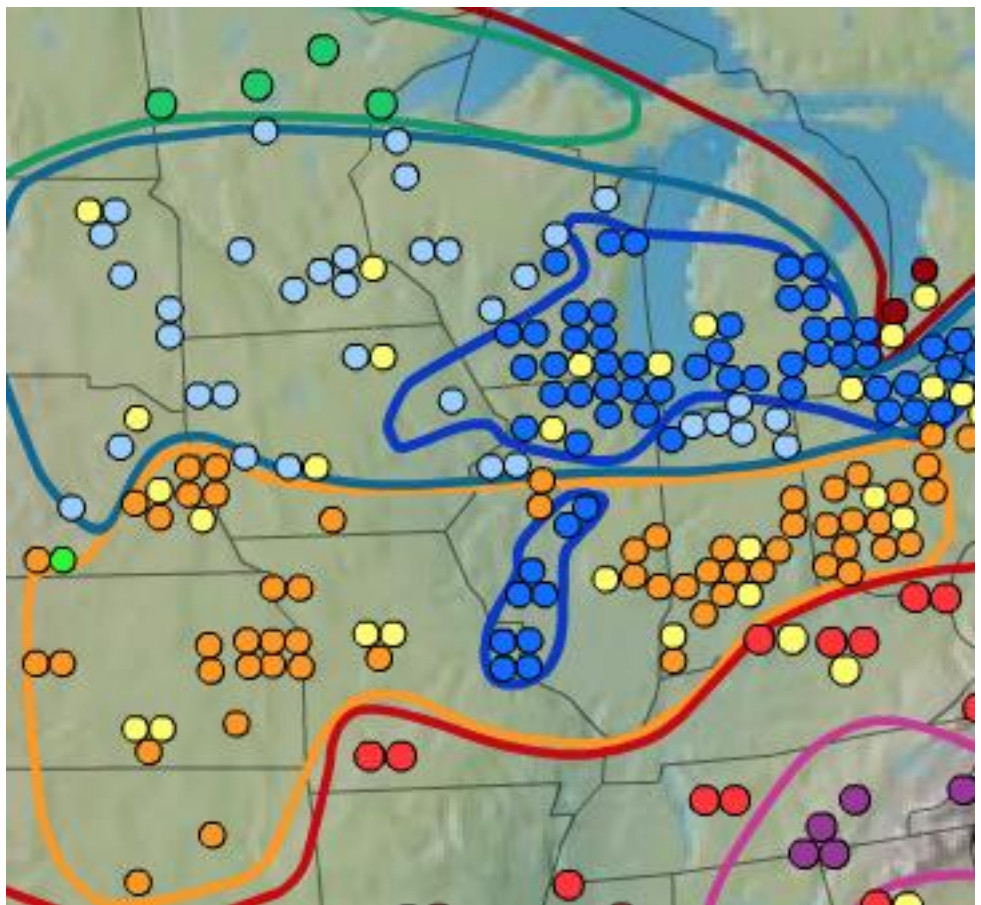

Map 2: St. Louis Corridor Extending into Midland's Dialect (adapted from the Atlas of North American English: "NAE Dialects")

The ANAE (2006) further reports on St. Louis Island phonological characteristics that do not match the general Midlands dialect, such as solid contrast of /o/ and /oh/, general raising of /æ/, with extreme fronting of /æ/ in bat and bad. The ANAE reports vowels in both cut and coat further back than the vowel in cot, and a spreading loss of its traditional merger of /ahr/ and /ohr/ to coalesce with the 
Northern Cities Vowel Shift (NCS). The ANAE additionally finds St. Louis Corridor characteristics similar to the Inland North and western New York State in that, unlike the Midland dialect surrounding this area, resistance to low back merger coincides with the raising of $/ æ / .{ }^{1}$ Labov (2007) states that the front-back approximation of /e/ and /o/ is "generally absent in the Midland region, except for St. Louis and nearby communities" (p. 373, italics added).

Labov (2007) also suggests that the NCS features not only reveal the strongest differentiation from the Midland dialect outside the St. Louis Corridor, but also that St. Louis speakers are further along on this shift than those from smaller cities within the corridor. This may be taken as evidence for diffusion along the corridor and not incrementally spread by children within the communities (i.e., transmission). While documenting the alignment of St. Louis with the Inland North, the ANAE notes that in numerous ways, St. Louis remains "more or less aligned with the Midland" (2006, p. 277). Even for the spread of the NCS, Labov notes another difference between the St. Louis Corridor and the Inland North: the change in the Inland North involved consistent chain-shifting rotating six vowels, while the corridor displays "a more irregular result," showing that sound changes diffuse "...individually rather than as a system" (2007, p. 383). The data used here are all phonological, date from the late 1990s, involve four Teslur speakers, and demonstrate somewhat differing language behavior.

The ANAE view of St. Louis concurs with Murray's $(1993,2006)$ accounts that documented other well-known features in the city of St. Louis. These include its stereotypical pronunciation of an icecream sundae ('sun-duh'), distinct from the day of the week ('sun-day'), and 'ar' pronunciation in like forty, born, former, and short, pronounced as 'farty,' 'barn,' 'farmer,' and 'shart.' Murray also reports that these pronunciations are rapidly transitioning. He states that pronunciations that were standard among young and old alike in the 1980s, were only rarely heard among younger generations when he wrote his 2006 paper (Spirited Speech, p. 127).

Murray (1993, 2006), however, also examined lexical and syntactic data from 1982 to 2001, and found that while pronunciation was moving towards the Inland North, the lexicon and syntax remained relatively unchanged. This finding suggests the need to consider lexical and syntactic data alongside 
phonological data to achieve a fuller picture. While lexical data taken by itself may be problematic, especially if arbitrary selections are used to independently establish dialect boundaries, a truer picture certainly emerges if such data is used to illuminate boundaries suggested by other analyses.

These observations, however, only begin to convey the unusual dialectal circumstances in Southwestern Illinois. Preston (2003), Bigham (2008), and others have observed a lack of detailed dialect research on communities in Southern Illinois, ${ }^{2}$ creating a gap in our knowledge of the already complex situation in Illinois. Despite the presence of a proposed dialect island encompassing the Greater St. Louis area, formal evidence, as well as informal and popular culture examinations of Southern Illinois and St. Louis dialects, suggest this area is less homogenous than previously thought. Friedman (2015) observed that the St. Louis Corridor appears to be simultaneously both a single dialect area and two distinct dialect areas. Zanuttini (2014) notes that it is important to raise questions about how micro-varieties of North American English change and depart from one another, because even small changes can ultimately yield different varieties of English. The varieties of English coexisting within a limited geographic region suggest the possibility of differing inventories of linguistic resources, even within what some judge to be a homogenous dialect area.

\section{RESEARCH QUESTIONS}

Our study of this region explores whether an analogous situation to Friedman's (2015) observations about the St. Louis Corridor occurs within Greater St. Louis. We consider whether there is evidence of unified divergence from dialects outside the metropolitan area, but with patterns that also reveal significant lexical and syntactic differences within the island. We query also, with Murray (2006), whether age affects the changes that we observe. More specifically, will we find evidence supporting transmission and/or diffusion across the dialect behavior in this region (Labov, 2007)?

While northern and southern areas of Illinois may be becoming more distinct in pronunciation due to the NCS and Southern Shift, we focus on lexical and syntactic data from this region. Moreover, we investigate the lexical and syntactic questions in a specialized manner, not focusing entirely on rare 
appearances of language variants, but rather by analyzing distributional differences of common and widespread terms across our area of study.

\section{METHODOLOGY AND RESEARCH VARIABLES}

We report the findings of a seven-year study focused initially on six counties in Southwestern Illinois closest to the St. Louis Metropolitan area, the "Metro East," but later expanded to include data from a total of 57 counties of Illinois and St. Louis and St. Louis County in Missouri. Beginning in 2010, we collected survey and interview data from respondents who lived in Illinois and the greater St. Louis area throughout their early formative years.

Survey data were collected from responses either in a face-to-face collection or through an online lexical and syntactic instrument. The survey asked for open choice responses to 34 lexical items and closed-choice responses to seven syntactic questions. For the face-to-face data collection, respondents provided verbal responses that the research team recorded. For the online open choice lexical items, respondents typed the terms they would use to identify items, and for the closed-choice syntactic responses, they would click on the choice that best represented their own usage. The lexical questions were based on questions posed by the HDS, while the syntactic questions came from the intuitions of linguistic faculty at Southern Illinois University Edwardsville regarding observed changes in local dialect.

The interview data included video and/or audio recordings made of participants reading word lists, responding to lexical and syntactic prompts, and answering interview questions. The interview portion queried whether respondents felt they spoke similarly to people in other regions of the state. Illinois residents were asked specifically about similarities and differences with St. Louis and vice versa. Respondents were also asked how far someone could travel away from where they grew up, but still sound like them and the people immediately around them (their family, neighbors, friends), and whether they had noticed any communities that are located very near to their own community, but where people talk in ways that noticeably differ from the way that they talk.

A total of 815 respondents participated in these two data collections. Nearly $95 \%$ of those participating were white, with the remainder self-identifying as African American, Asian, Hispanic, Two 
or More Races, or other. ${ }^{3}$ The dataset for analysis was narrowed by removing those respondents whose first language was not English, whose formative years were spent outside of Illinois or St. Louis, or who did not provide sufficient demographic data to identify where they grew up or had lived. This narrowing yielded 649 usable data collections for analysis, about $80 \%$ of the original pool. The qualitative section of this paper provides additional data from 47 targeted interviews regarding specific lexical and syntactic items, observations regarding the use of items, social media, and impressionistic reports in local print media.

\section{SURVEY VARIABLES}

Table 1 provides a brief description of each of the variables used in this analysis, along with how each was measured. We provide summary statistics for each of these variables in Appendix B.

Table 1: Variable Description and Measurement

\begin{tabular}{|c|c|}
\hline$\underline{\text { Variable }}$ & Measurement \\
\hline \multicolumn{2}{|l|}{ Dependent Variables } \\
\hline $\begin{array}{l}\text { What do you call the wheeled contraption in which you carry } \\
\text { groceries at the market (Wheeled Contraption)? }\end{array}$ & $\begin{array}{l}\text { 1: Shopping Cart; 2: Two or More Things Stated; 3: Cart; 4: Grocery } \\
\text { Cart; 5: Grocery Basket; 6: All Others }\end{array}$ \\
\hline $\begin{array}{l}\text { What generic term would you use for any blended, semi-frozen, } \\
\text { cream or milk-based drink (Milk-Based Drink)? }\end{array}$ & $\begin{array}{c}\text { 1: Milkshake; 2: Two or More Things Stated; 3: Shake; 4: Malt; 5: } \\
\text { Smoothie; 6: All Others }\end{array}$ \\
\hline $\begin{array}{l}\text { What do you call the device that provides drinking water with the } \\
\text { push of a button, usually found in an office hallway or at a } \\
\text { gymnasium (Drinking Water Device)? }\end{array}$ & $\begin{array}{l}\text { 1: Water Fountain; 2: Two or More Things Stated; 3: Water Cooler; } \\
\text { 4: Water Jug; 5: Drinking Fountain or Fountain; 6: All Others }\end{array}$ \\
\hline $\begin{array}{l}\text { What do you call the little grey creature (looks like an insect) that } \\
\text { rolls up into a little ball if you touch it (Grey Creature)? }\end{array}$ & $\begin{array}{c}\text { 1: Pillbug; 2: Two or More Things Stated; 3: Roly Poly; 4: All } \\
\text { Others }\end{array}$ \\
\hline $\begin{array}{l}\text { If you are cold, and little points of skin begin to raise up on your } \\
\text { arms or legs, you have }\end{array}$ & $\begin{array}{l}\text { 1: Goosebumps; 2: Two or More Things Stated; 3: Goosepimples; 4: } \\
\text { All Others }\end{array}$ \\
\hline $\begin{array}{c}\text { What is the general term that you use for the meal that you eat in the } \\
\text { evening (Meal Eaten in the Evening)? }\end{array}$ & 1: Dinner; 2: Two or More Things Stated; 3: Supper; 4: All Others \\
\hline $\begin{array}{l}\text { What is the insect that looks like a large thin spider and skittles } \\
\text { across the surface of the water (Large, Thin Spider that Skittles)? }\end{array}$ & $\begin{array}{l}\text { 1: Waterbug; 2: Two or More Things Stated; 3: Water Spider; 4: } \\
\text { Water Strider; 5: Water Skimmer; 6: Water Skipper; 7: All Others }\end{array}$ \\
\hline \multicolumn{2}{|l|}{ Independent Variables } \\
\hline Age & Numeric Age \\
\hline Sex & 0 : Female; 1 : Male \\
\hline Education & $\begin{array}{l}\text { 1: Less than High School or Trade School; 2: High School Diploma; } \\
\text { 3: In College or Some College ; 4: Bachelor's Degree; 5: Masters, } \\
\text { Ph.D., or other graduate degree. }\end{array}$ \\
\hline Annual Income & 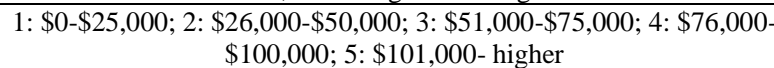 \\
\hline Metro East & 1: Metro East; 0:All Other Regions \\
\hline St. Louis City and County "Missouri side" & 1: St. Louis City or County; 0: All Other Regions \\
\hline
\end{tabular}


Dependent Variables. We drew upon a representative sample of 7 of the 34 lexical survey questions, as reporting on all 34 items would make this analysis intractible. We asked respondents to state what they would name the wheeled contraption that carries groceries; the generic term for blended, semi-frozen, cream, or milk-based drinks; the device that provides drinking water with the push of a button; the name of the grey creature that rolls up into a little ball if touched; the small points of skin that begin to rise on arms or legs; the general term for the meal eaten in the evening; and the name of the insect that looks like a large, thin spider and skittles across the surface of the water.

Then, we placed the wide number of free response options into logical groupings for statistical analyses. Using the most common response as the base, we grouped other less frequent responses. For example, those who provided two or more answers to a response were in one group. Similarly, those who provided responses substantially similar to one another were grouped into a single response option. For instance, those who called the device that provides drinking water with the push of a button a drinking fountain or fountain were placed in a single group. Finally, variant responses that were uncommon outliers were collapsed into a category of all others. The exact wording of all questions used in this analysis, along with the complete list of ways in which the response options on the different questions were collapsed is available in Appendix A.

Independent Variables. We used six independent variables. First, we asked respondents to report their age and gender. All respondents who answered this question self-identified as either male or female. Next, our respondents reported their annual income group from among five options that ranged from zero to $\$ 25,000$ to over $\$ 101,000$. Then, they reported their level of education. This variable has five values that range from having less than a high school education to having advanced graduate degree(s). Finally, we used two binaries for those from the Missouri side of the St. Louis metropolitan area and those who live in the Illinois counties in this region. We defined those who lived on the Missouri side of the Mississippi River as those who lived in St. Louis City or St. Louis County. ${ }^{4}$ Second, we defined those in the Metro East as living in St. Clair, Madison, Macoupin, Clinton, Jersey, and Bond Counties. 
Analysis of Variables. Each of our seven dependent variables were measured at the nominal level, which communicates differences between subjects on some characteristic. Because the survey responses were collapsed into a series of unordered choices, we used a multinomial logistic regression to test our theoretical expectations, as this is the most appropriate technique given the structure of our dependent variables. ${ }^{5}$ As an inferential statistical technique, multinomial logistic regression also allows us to draw more accurate conclusions while accounting for an array of independent variables within the same modeling structure. By contrast, descriptive statistics do not provide the same explanatory leverage.

However, our data contains individuals distributed across counties. Consequently, computing our standard errors by normal processes as the basis by which we conduct our tests of statistical significance is likely inappropriate (Cameron and Miller, 2015), since it is possible that the values of responses in one county would be influenced by those in adjacent counties. For example, it is possible that responses from those in Madison County, Illinois may be influenced by those in St. Clair County, an adjacent county. Thus, our analysis needs to account for the likely presence of these types of situations in the data, also known as spatial autocorrelation.

To do so, we employ clustered standard errors and computed our tests of statistical significance using cluster-adjusted t-statistics using pairs cluster bootstrapped t-statistics (Esarey and Menger, Forthcoming). ${ }^{6}$ This method of computing standard errors, and by extension, t-statistics allows a more accurate computation of standard errors in cases like ours - where we have a relatively small number of clusters - because we can more effectively limit the number of false positives (Esarey and Menger, Forthcoming). In turn, this allows us to have more accurate tests of statistical significance and decreases the likelihood that we report inaccurate findings.

\section{QUANTITATIVE SURVEY RESULTS}

The results from the multinomial logistic regressions contained in Appendices C and D furnish statistically significant evidence that favors the presence of a dialect island in the Greater St. Louis area, but with lexical differentiation between St. Louis and the Metro East. Further, we find evidence that indicates numerous age-related differences. 
Because the coefficients in any multinomial logistic regression do not have a straightforward interpretation, we generate several figures in which we visualize the predicted probabilities of each response option. ${ }^{7}$ To generate these figures, we changed the value of one our independent variables while holding all others constant so that we can interpret our statistical models in light of the change in predicted probabilities, relative to the baseline observation. ${ }^{8}$ More specifically, we generated the change in predicted probabilities of giving each response option given a change in the value of one of our independent variables. Below, we graphically illustrate these comparisons.

\section{ST. LOUIS AND THE METRO EAST}

When we examine responses from St. Louis and the Metro East to a prompt such as, "If you are cold, and little points of skin begin to raise up on your arms or legs, you have ," we see minor differences between the halves of the island. In addition, responses to the prompt "What is the insect that looks like a large thin spider and skittles across the surface of the water?" show even less variation. We note the similarity in patterning in St. Louis and the Metro East, illustrated in Figures 1 and 2. For these and all figures contrasting those who live on the Missouri side of the Mississippi River relative to those in the Metro East, the solid line corresponds to the Missouri side, while the dashed line illustrates the Metro East. In addition, the circles correspond to points on the Missouri side while the triangles correspond to points on the Illinois side. ${ }^{9}$

We find that those who live on the Missouri side of the St. Louis metropolitan area are $6.2 \%$ less likely to say water skipper, but are $3.7 \%$ more likely to say water bug, as opposed to all other options of large, thin spiders, and relative to those who live elsewhere. Compared to those who live someplace else, Missouri side residents are .7\% less likely to say goosepimples, $.7 \%$ less likely to say two or more options, $.9 \%$ less likely to say something else, but are $2.3 \%$ more likely to say goosebumps. Relative to non-Metro East residents, those who live in the Metro East are no more likely to choose any single option over any of the others when we examine both questions. These response patterns differ slightly, but with substantial similarity in patterning, precisely what we would expect in a dialect island. We explore the presence of a dialect island in the St. Louis area further in the next section. 
Figure 1: 'Water Bug' in St. Louis and Metro East:

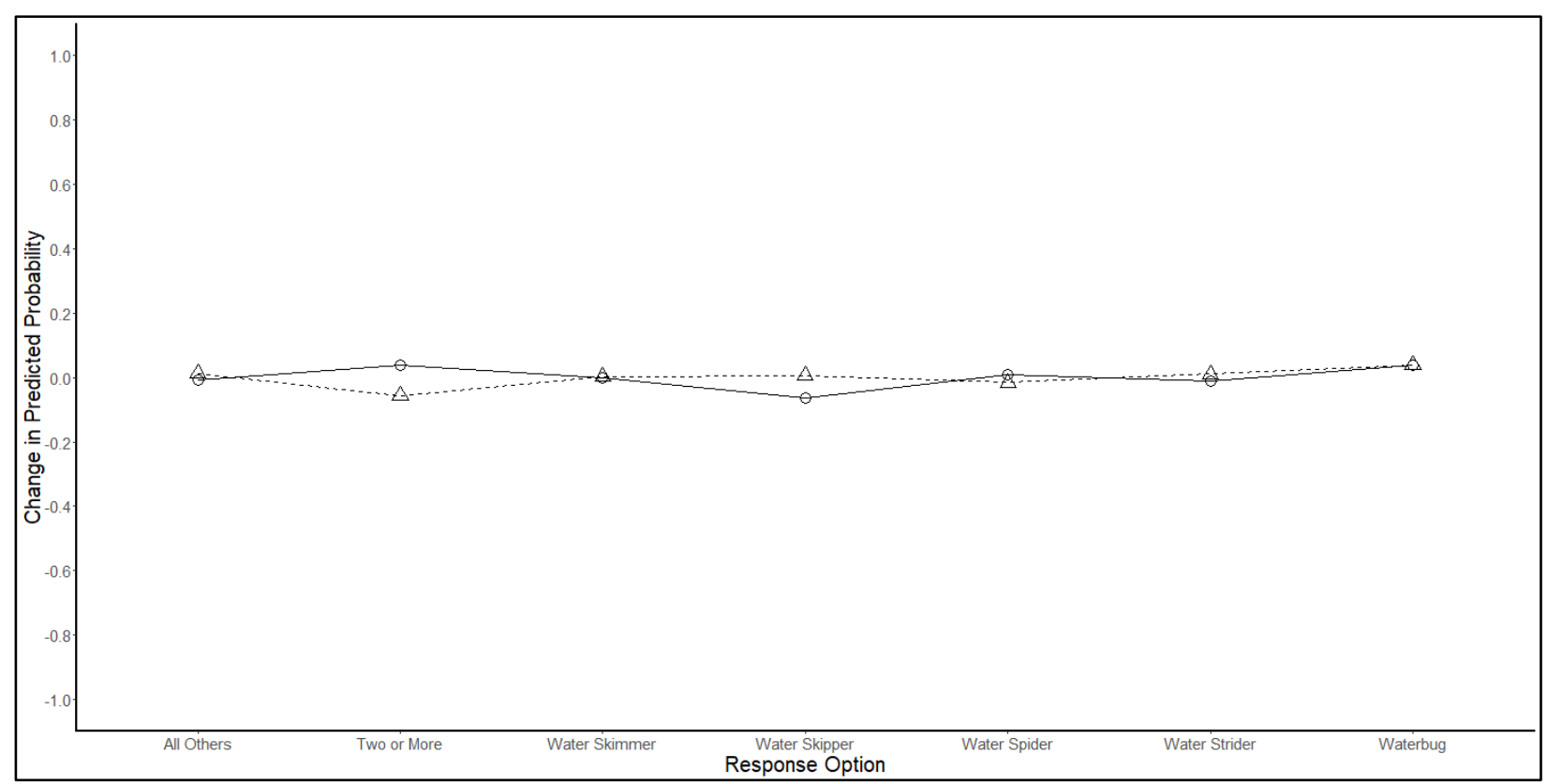

Figure 2: 'Types of Bumps when Cold' in St. Louis and Metro East

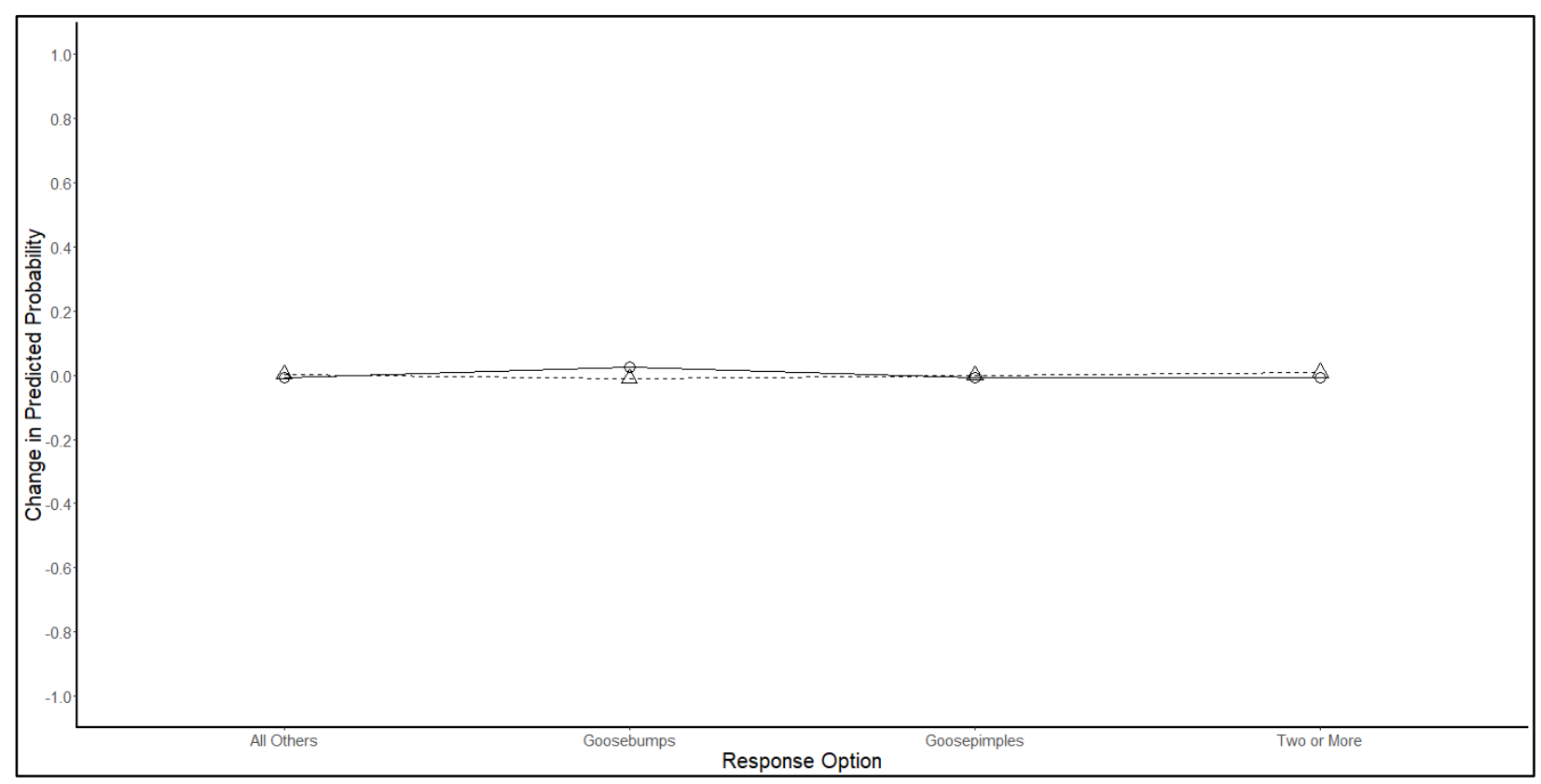

From these visualizations, it appears that there are few differences between the Missouri side and the Metro East. For other lexical items, however, we find significant differences between the parts of the island. For example, Figure 3 shows responses to the prompt, "What is the general term that you use for the meal that you eat in the evening?" 
Figure 3: 'Evening Meal' St. Louis and Metro East Graphs

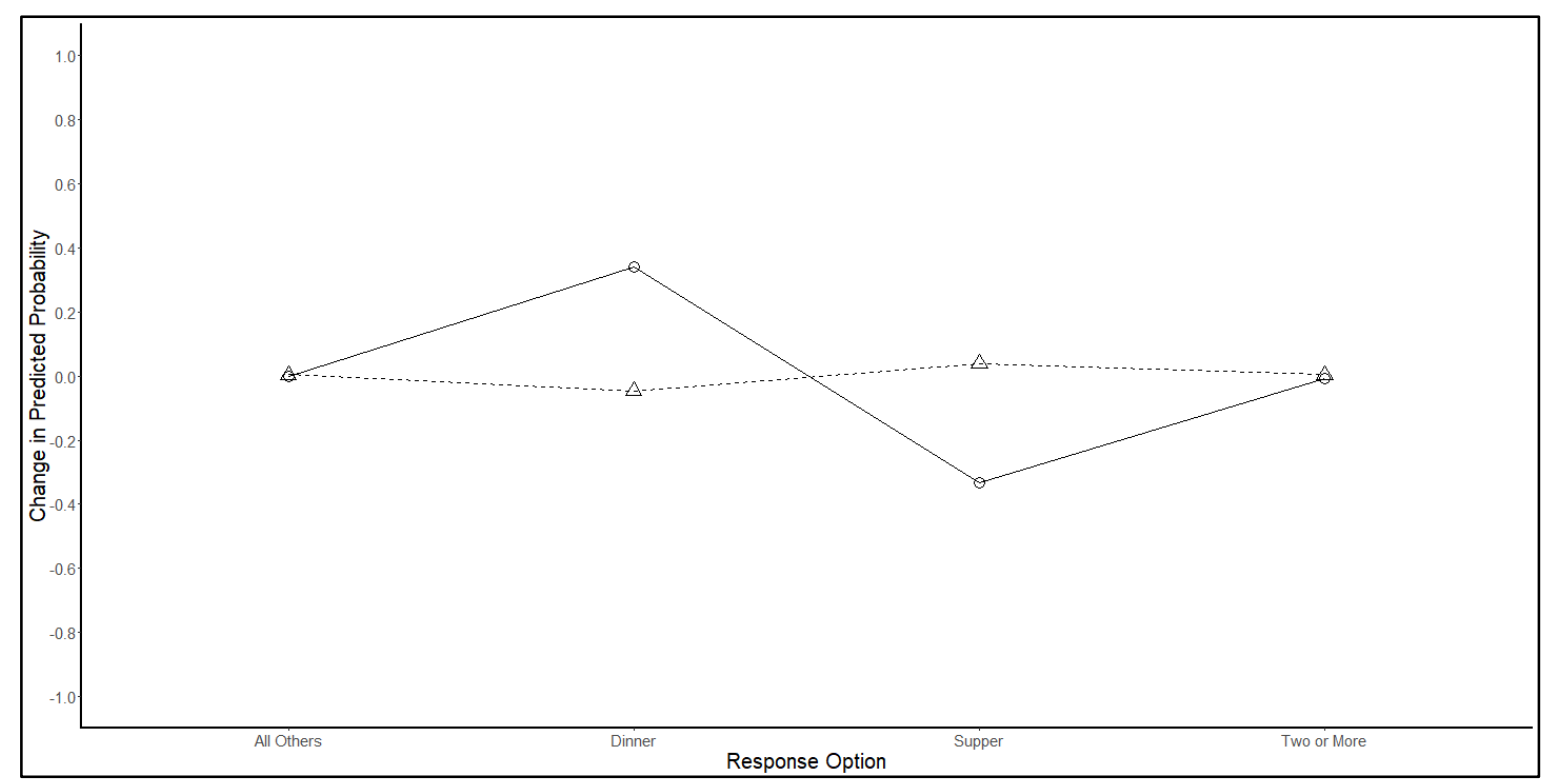

For this question, there were clear differences in predicted probabilities for St. Louis and Metro East, compared to those who live elsewhere. Relative to those who live someplace else, people who live on the Missouri side of the Mississippi River are 34.02\% more likely to say dinner, $33.19 \%$ less likely to say supper, and are .8\% less likely to give two or more options. Thus, a response of dinner rather than supper is more likely to occur with St. Louis residents. Likewise, when we look at responses to the prompt, "What do you call the device that provides drinking water with the push of a button, usually found in an office hallway or at a gymnasium?" we see strong differentiation between the Missouri side and that of the Metro East, as illustrated in Figure 4. 
Figure 4: 'Water Dispenser' in St. Louis and Metro East

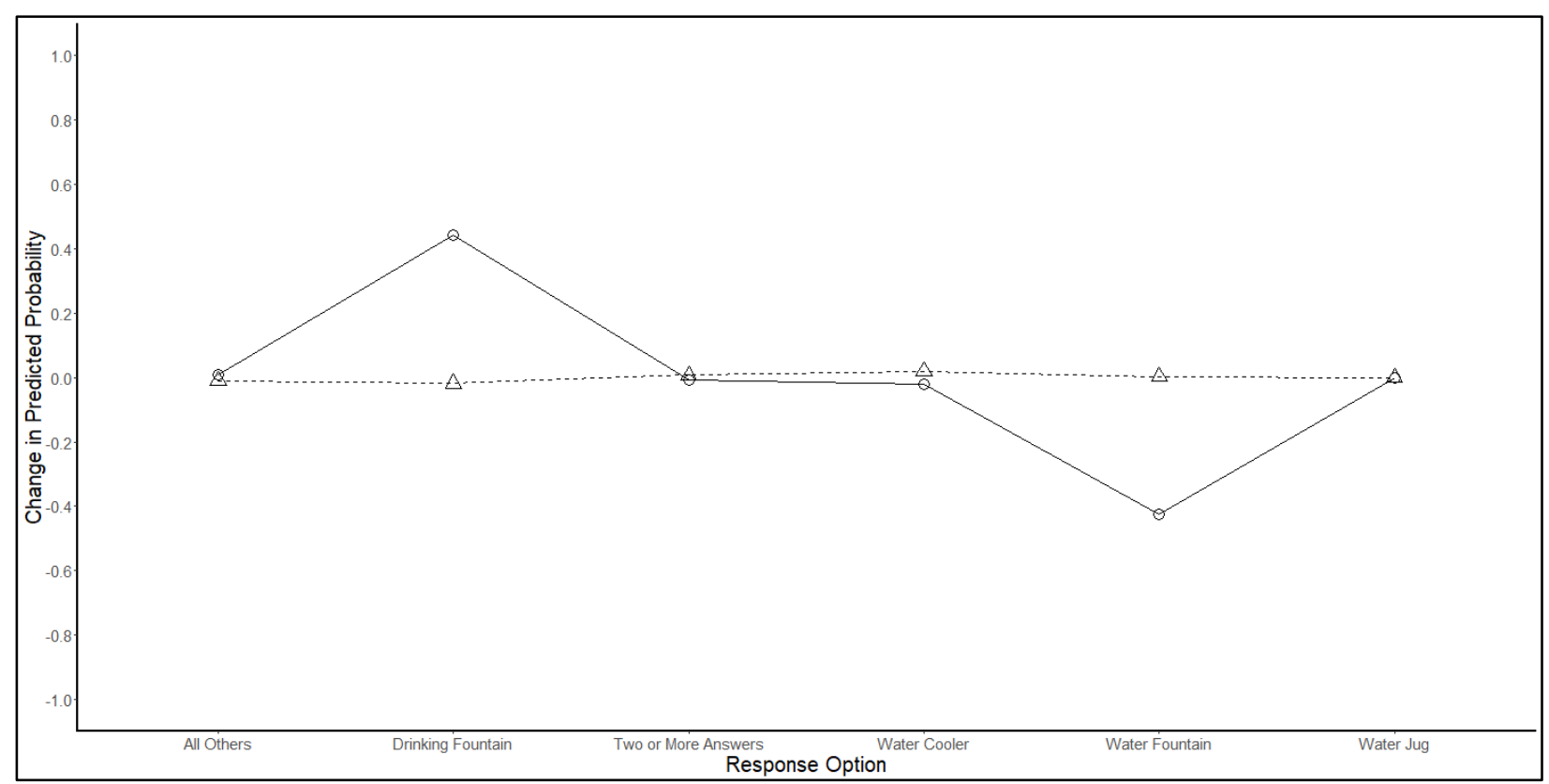

Figure 4 reveals that those who live on the Missouri side are $44.22 \%$ more likely to say drinking fountain, and $.9 \%$ more likely to respond with all other options, relative to those who live elsewhere.

Thus, St. Louis speakers are far more likely to respond drinking fountain or anything else as compared with water cooler or water fountain. This same kind of patterning, showing differences between St. Louis and Metro East, also appears in response to questions about the name of the "wheeled contraption in which you carry groceries at the market" and the term used for "any blended, semi-frozen, cream or milkbased drink." Figures 5 and 6 illustrate these points. 
Figure 5: 'Grocery Cart' in St. Louis and Metro East

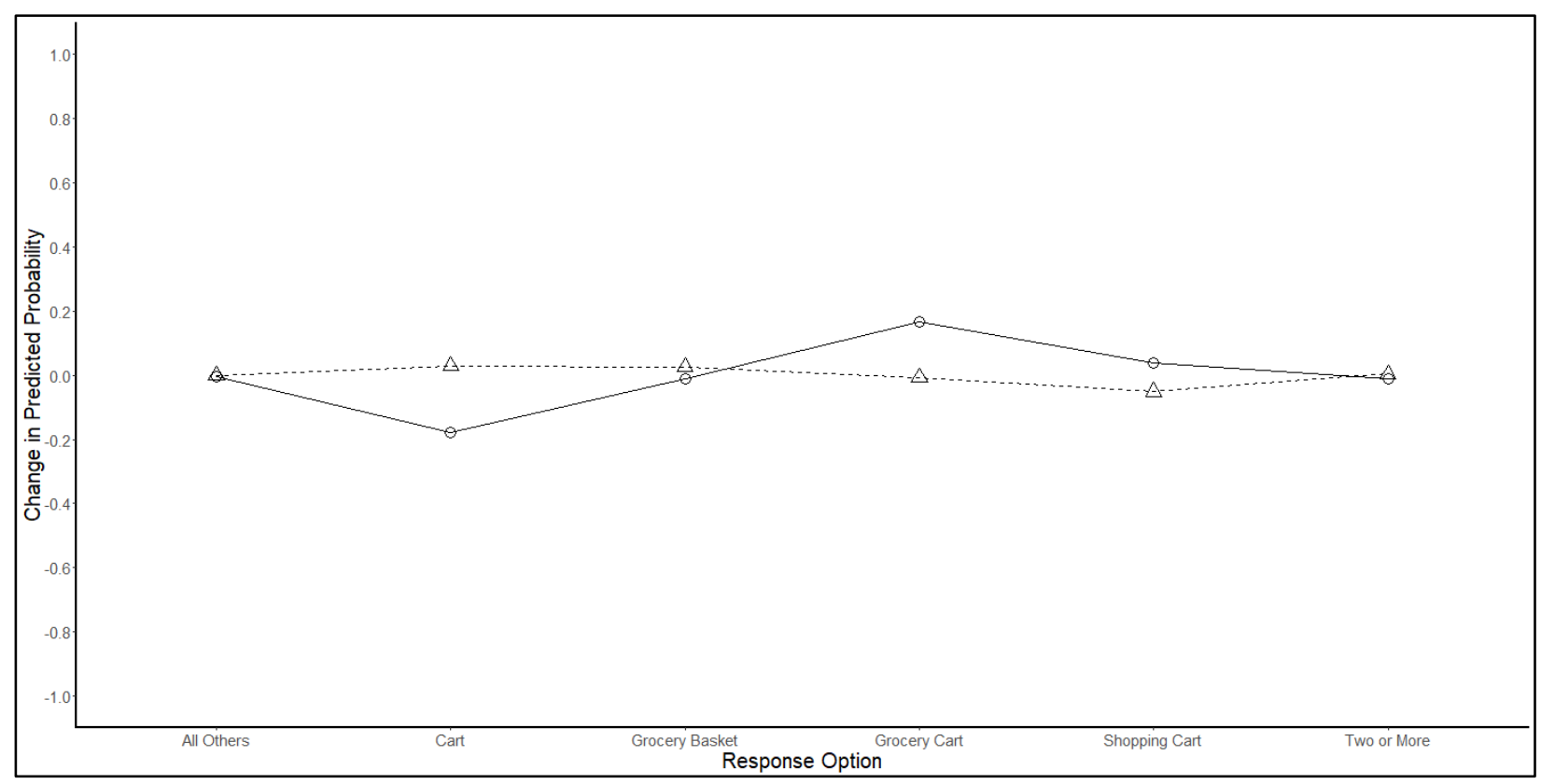

Figure 6: 'Shake' in St. Louis and Metro East

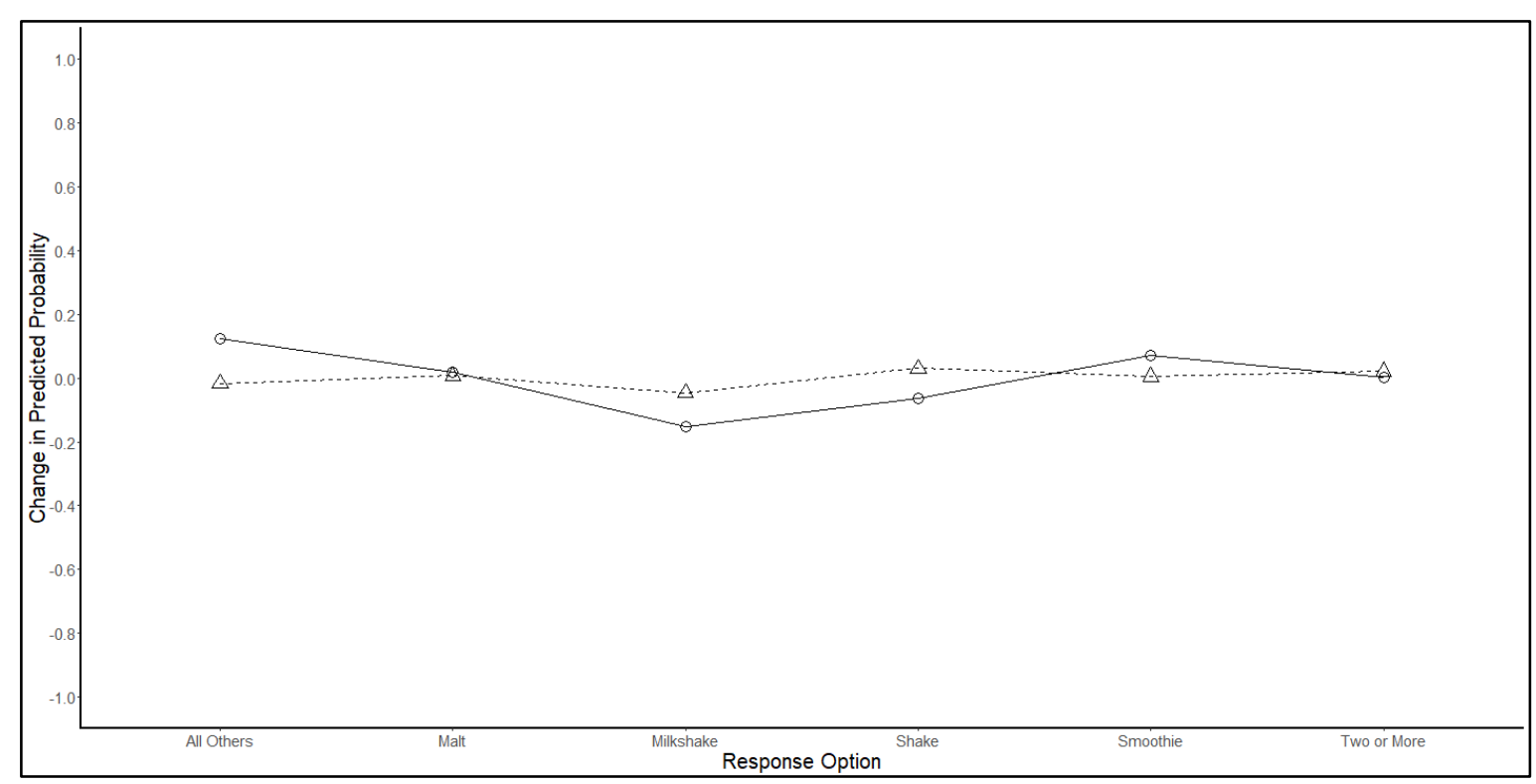

Figure 5 represents that those who live on the Missouri side are $1.03 \%$ less likely to say grocery basket and $1.3 \%$ less likely to give two or more answers to this question, but are $3.8 \%$ more likely to say shopping cart compared to those who reside elsewhere. Relative to those who live someplace else, Metro East residents are $2.82 \%$ more likely to say cart, but are $5.11 \%$ less likely to say shopping cart. As Figure 6 shows, we learn that those who live on the Missouri side are $15.37 \%$ less likely to say milkshake and are 
$6.27 \%$ less likely to say shake compared to those who live someplace else. Compared to those who live elsewhere, Metro East residents are $4.65 \%$ less likely to say milkshake, but are $3.05 \%$ more likely to respond shake. Thus, St. Louis residents are less likely to say grocery basket but are more likely to say shopping cart,' and less likely to say milkshake and shake.

\section{A GREATER ST LOUIS DIALECT ISLAND}

Lexical data supporting the presence of a dialect island in this way must show, first, that the Missouri and Illinois halves of Greater St. Louis reveal a similar response pattern and, second, that this pattern is different from what is found in the other Illinois counties outside Greater St. Louis. Figures 1 and 2 provide the strongest initial evidence that suggests a dialect island, as we have similar response patterns across the Missouri and Illinois halves of the St. Louis metropolitan area. ${ }^{10}$ When we look at responses from within Greater St. Louis and compare them to responses received in the areas of Illinois outside of the island, a complementary story emerges, with the results from the multinomial logits from these analyses shown in a series of tables in Appendix C. Figure 7 graphically illustrates significant response differences between Greater St. Louis and other Illinois counties outside this region.

Figure 7: 'Grocery Cart' in Greater St. Louis

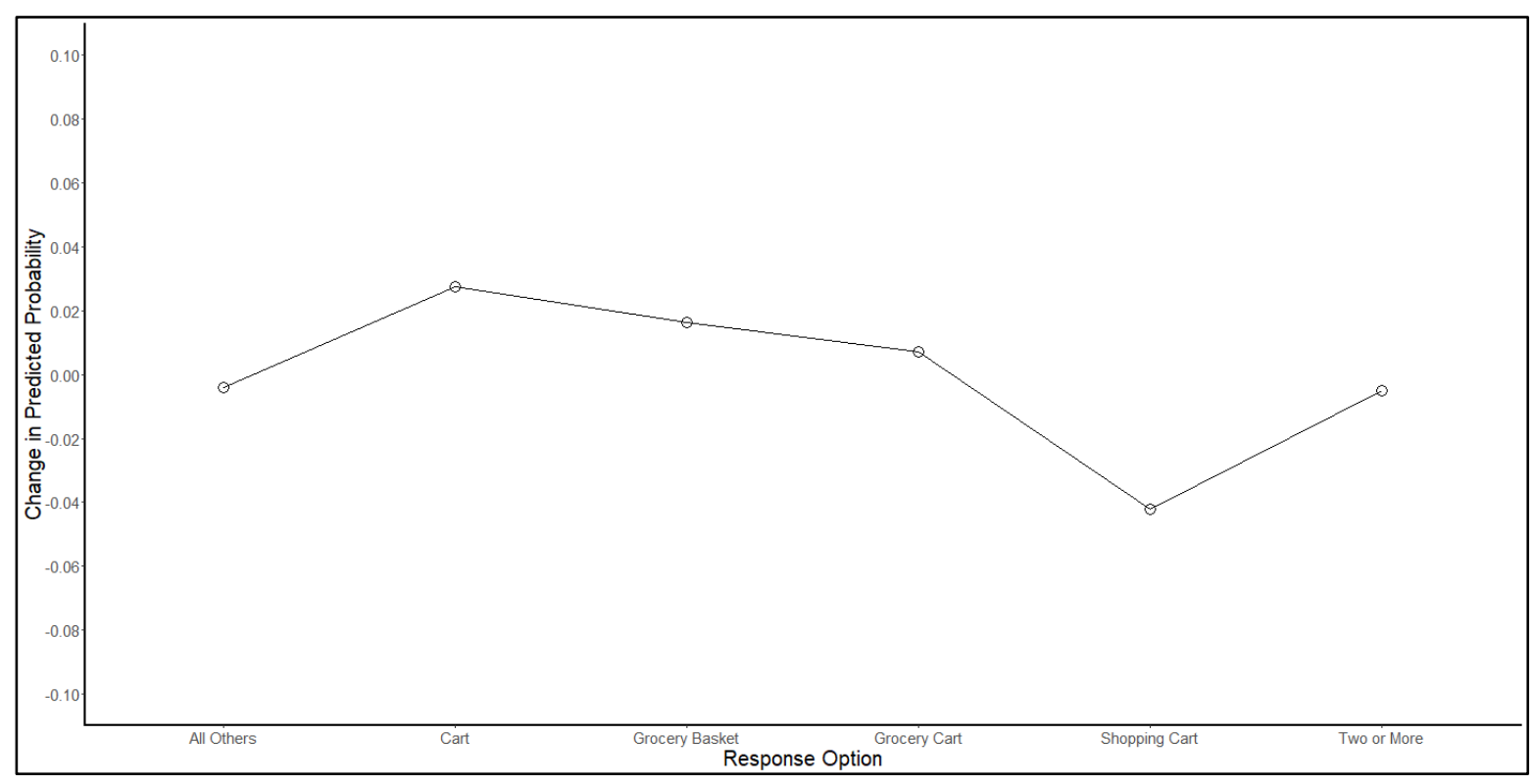


We see in Figure 7 that, compared to the rest of Illinois, respondents in the Greater St. Louis are $2.76 \%$ more likely to say cart and $4.21 \%$ less likely to say shopping cart than respondents in Illinois outside the region, when asked to identify the name of the "wheeled contraption in which you carry groceries at the market." That said, Figure 7 demonstrates that the Greater St. Louis area shows a different lexical patterning than the rest of Illinois. Significant differences are also found related to naming the “evening meal" (Figure 8).

Figure 8: 'Evening meal' in Greater St. Louis

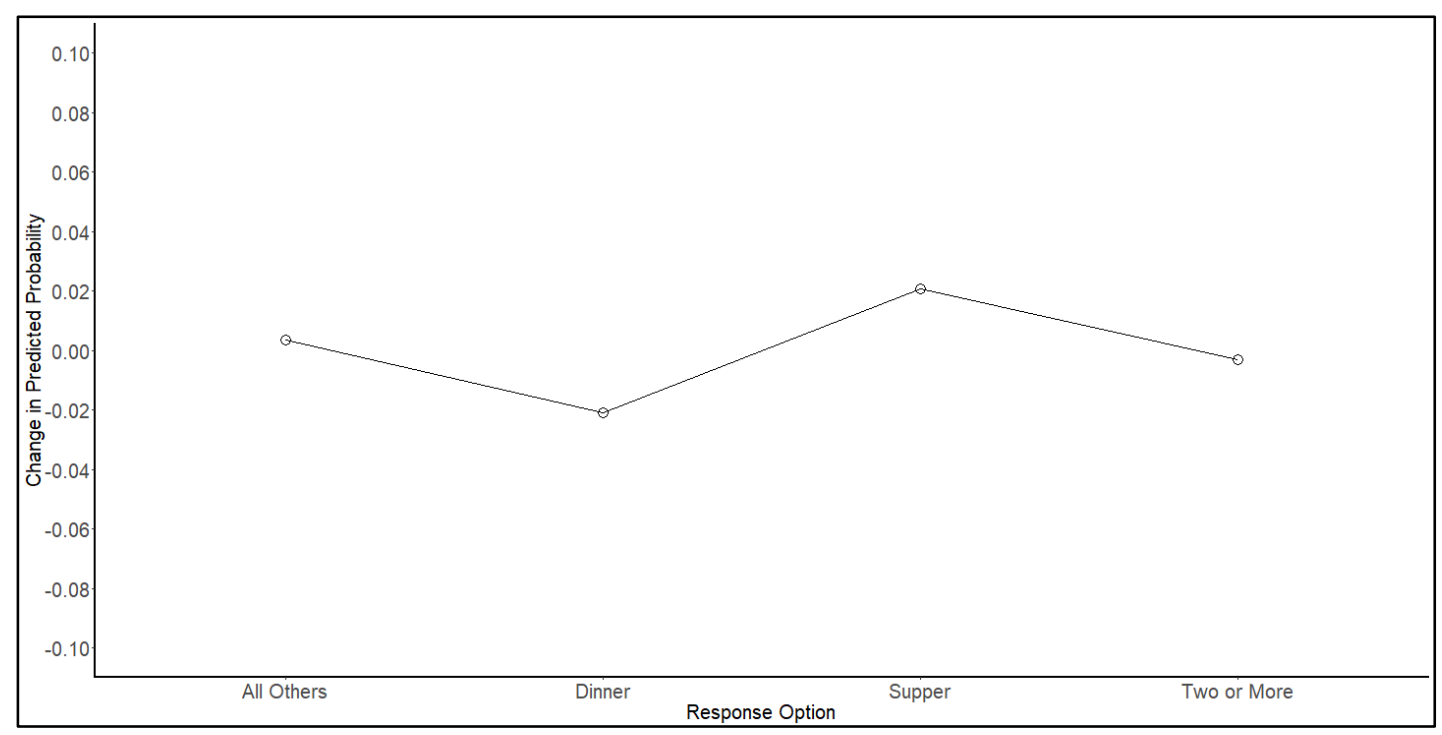

The predicted probability of saying "supper" increases by $2.06 \%$ when one is a resident of Greater St. Louis, relative to those who reside someplace else. Additionally, the predicted probability of saying "dinner" decreases by $2.11 \%$ when one is a St. Louis area resident, relative to one who lives elsewhere. Response differences are also seen between Greater St. Louis and the rest of Illinois to a prompt regarding the generic term used for any blended, semi-frozen, cream or milk-based drink (Figure 9). 
Figure 9: 'Shake' in Greater St. Louis

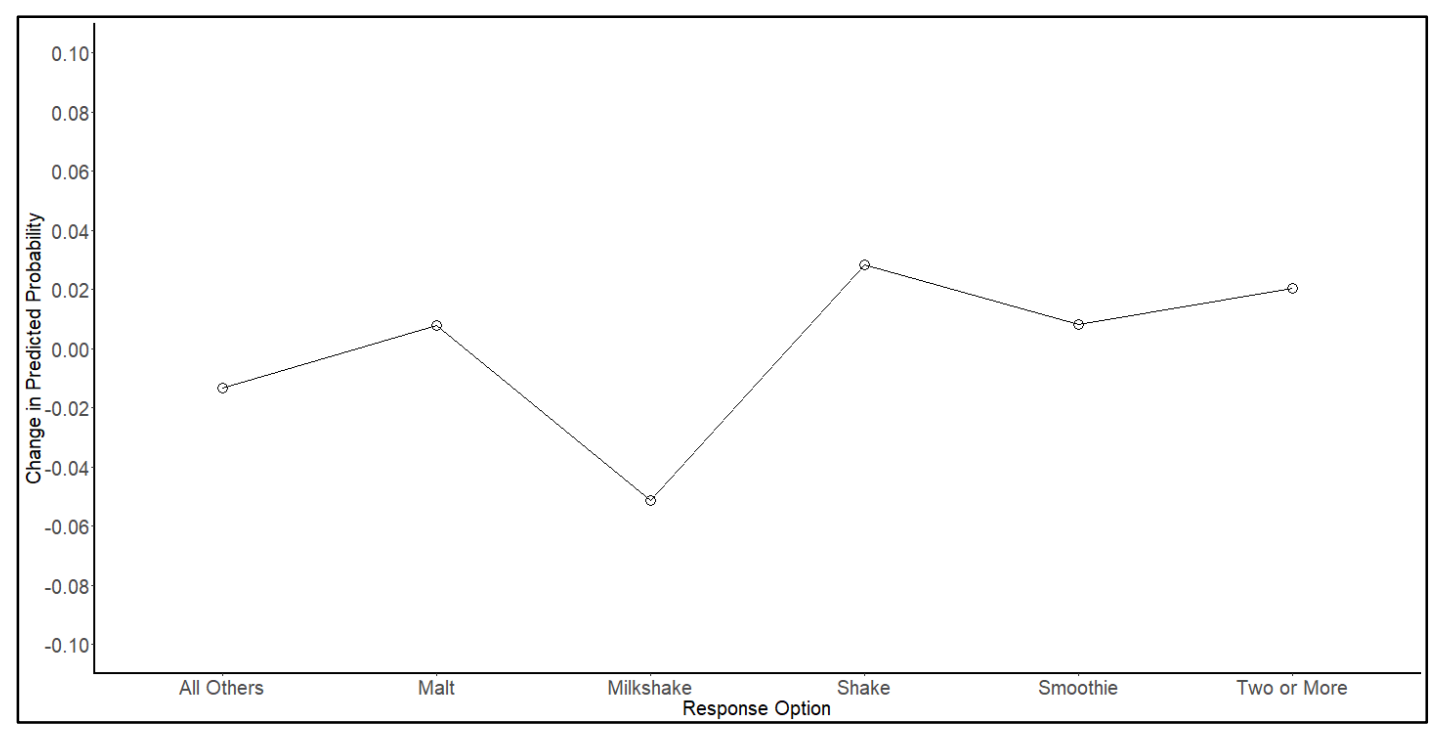

Figure 9 represents that Greater St. Louis as a whole is $2.82 \%$ more likely to give "shake" as a response than other Illinois areas, while it is $5.14 \%$ less likely to respond with "milkshake." Thus, the evidence in Figures 1, 2, 7, 8 and 9 indicates lexical support for a dialect island in Greater St. Louis, both by showing internal coherence in the island and clear variance with Illinois counties outside of Greater St. Louis.

\section{AGE DIFFERENCES IN THE ISLAND}

Our results also showed age related differences within the island, with patterning that sometimes matched that of either St. Louis or Metro East, but often differed from both based on the results from our multinomial logits in Appendix D. We illustrate these trends through Figures 10 and 11. The left side of Figure 10 illustrates the response options for grocery cart, while the right side introduces those options for roly poly. 
Figure 10: 'Grocery Cart' and 'Roly Poly' by Age

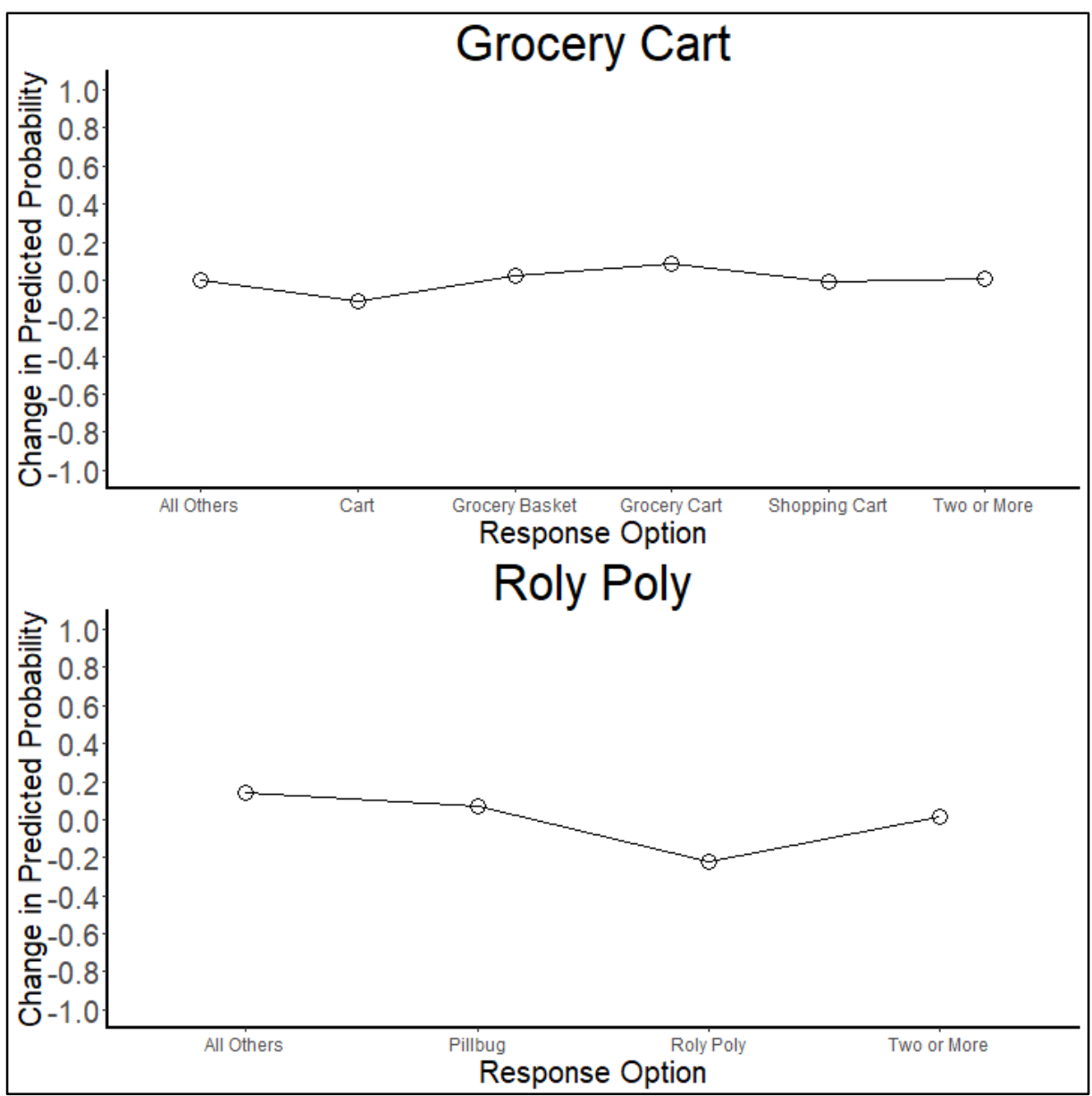

When we examine the choice of grocery cart, we find that a one standard deviation increase in a respondent's age (from 43 to 60 ) is connected with an increase in the predicted probability of naming this object grocery cart by $8.5 \%$, but a decrease in the probability of naming this object shopping cart by $.5 \%$. When asked what to name the little grey creature that rolls up into a ball, a one standard deviation increase in age is associated with a $6.8 \%$ increase in the predicted probability of calling it a pillbug, and a $13.82 \%$ increase in the probability of calling it something else, but a $21.79 \%$ decrease in the probability of calling it a roly poly. Thus, the older a respondent is, the more likely they are to say grocery cart rather than other responses, and the older a respondent is, the less likely they are to say roly poly in response to the prompt, "What do you call the little grey creature (looks like an insect) that rolls up into a little ball if 
you touch it?" This pattern was at variance with Metro East respondents, who showed no preference between the terms.

Differences related to age may also be seen in responses regarding the evening meal and the label given to the ice cream drink. Figure 11 illustrates these differences, with the left pane corresponding to the evening meal, while the right illustrates the ice cream drink.

Figure 11: 'Evening Meal' and 'Shake' by Age

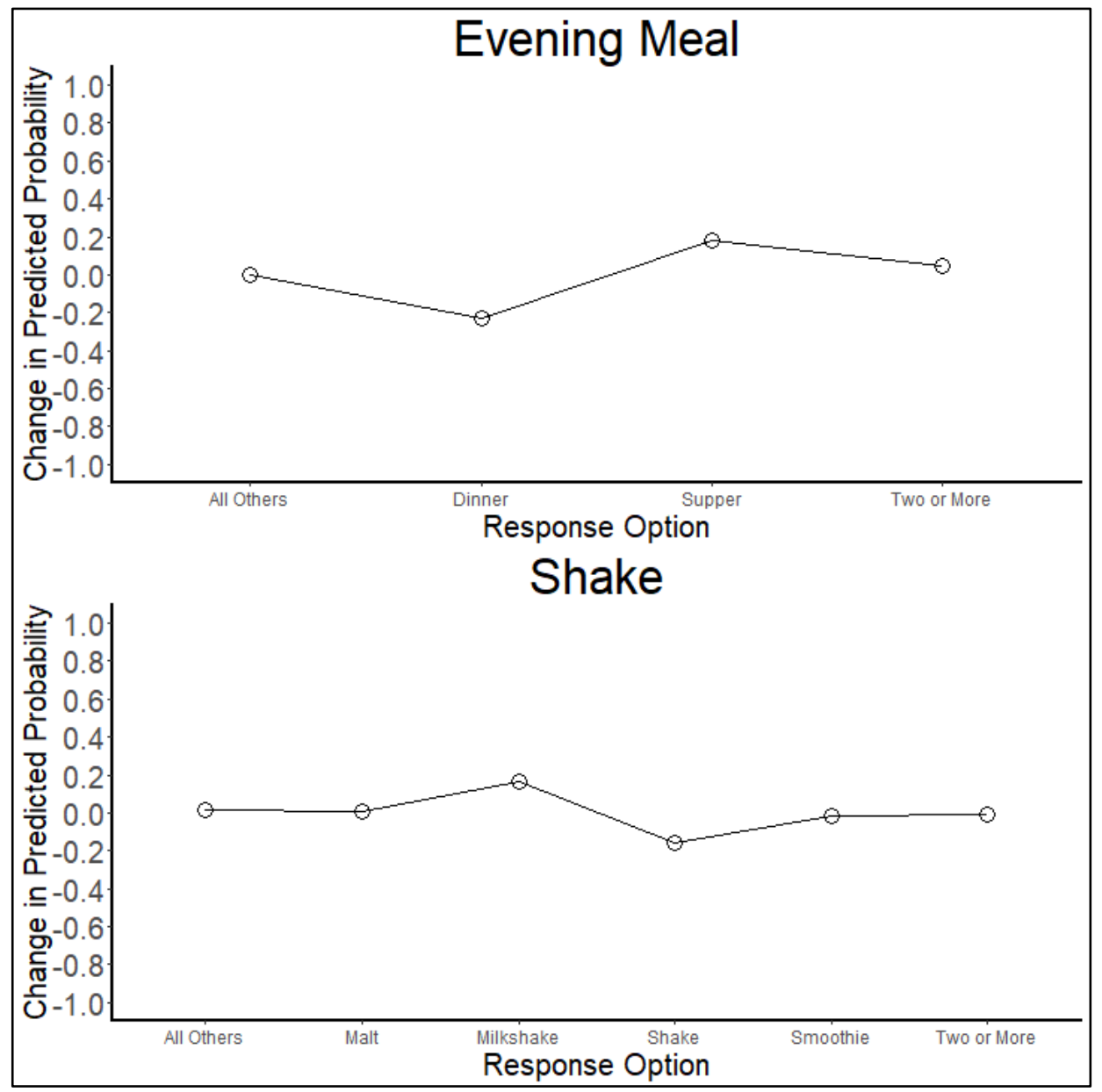

Figure 11 indicates that a one standard deviation increase in age is connected with a $22.94 \%$ decrease in the predicted probability of calling the evening meal dinner, but an $18.33 \%$ increase in the predicted probability of calling this meal supper. The older a respondent is, the more likely they are to call the evening meal supper, with patterning stronger than the Metro East more generally, and with a reversal of the predicted choice of St. Louis respondents. Further, Figure 11 indicates that a one standard 
deviation increase in age is associated with a $.6 \%$ increase in the predicted probability of calling the ice cream a malt, but a $15.51 \%$ decrease in the predicted probability of calling this drink a shake. Thus, malt is the preferred answer of older respondents, and this contrasts with both St. Louis and Metro East respondents who display somewhat differing preferences.

In sum, the interview data revealed lexical evidence that supports existing accounts of a dialect island in Greater St. Louis, while it also revealed distinctive vocabulary choices appearing in St. Louis that was uncharacteristic of the Metro East, and vice versa. We further found age-related syntactic and lexical choices. The results of the survey data reveal patterns of both lexical similarity and lexical difference in the St. Louis dialect island. The survey data also shows that an aging population in Greater St. Louis is likely to make lexical choices that differ from younger respondents, who do not entirely replicate the lexical and syntactic choices of the older generation.

\section{QUALITATIVE INTERVIEW RESULTS}

Our interview responses, social media discussions, and print media provide another method of looking at language behavior in Greater St. Louis. These sources uncovered local residents with distinct conceptions of commonality in the dialect island, distinctions between the broad halves of the island, and the importance of age as factor in the language variation of the region. These results are based on an analysis of the responses of 47 individuals of varying ages, genders, and locations within Greater St. Louis. The interviews consisted of many open-ended questions and recorded responses to questions about Greater St. Louis and Illinois. Benson (2003) highlighted the importance of perceptions and folk beliefs in the mapping of dialect boundaries, and we find additional support for the quantitative results in the study through these qualitative means.

Interview responses regarding Greater St. Louis referred to both sounds and vocabulary.

Respondents stated that they believed people in the metropolitan area speak differently than those in other parts of Missouri or Illinois. Interviewees did not, of course, identify this commonality as island participation in the Northern Cities Vowel Shift. They had a vague sense that Greater St. Louis differed from a "twang" to the west in Missouri or the "Hoosier talk" to the east in rural Illinois. While Murray's 
(2003, 2006) work documented that St. Louis dialect has some distinctive phonological forms that differentiate it in certain ways from the Inland North, our interviewees could only provide specificity regarding some strong lexical preferences within both areas of the island-for example, the well-known island use of soda in the island over pop (to the north), or coke (to the south).

Some respondents from both sides of the island used the term " $T-R a v$ " for toasted ravioli, a term not commonly found in areas of Illinois outside Greater St. Louis. Media uses of the term have also arisen, as in the 2015 article, "T-Rav is all the rage.” Popular media comments also support a psychological notion of the island, as illustrated by this comment on a online dialect article written by Edward McClelland (2016), "What's very strange is that if you go even slightly outside of the populated areas of the metro, the typical St. Louis/Chicago urban speech disappears and is replaced by a marked rural accent. Very bizarre that this happens so abruptly."

Despite popular perceptions of similarities in the western and eastern halves of the dialect island, there is also a clear sense of differences. For example, while St. Louis area respondents reported that they had heard the phonological variants related to sundae and forty-four in St. Louis, Metro East respondents who had heard these identified them solely with St. Louis, but not with their own Metro East dialect. The Metro East also contained distinctive vocabulary. In parts of the Metro East, numerous interviewees spoke of yip yips as a term for what many others call sloppy joes. This term was largely unattested among St. Louis residents. On social media and cooking recipe websites, though, we found other instantiations of this term outside the Metro East, from residents in Southwestern Illinois and one instantiation in Lebanon, MO, in the south-central region of the state. Appearing only in the northwestern Metro East area of the dialect island (at least among our interviewees) was tacky yacky as a variant for teriyaki chicken, and the pronunciation the term height as /hai $\theta /$.

Age-related distinctions also appeared. All of the stereotypical St. Louis features, mentioned by Murray (2006), were identified by respondents as something that older people might say, but which are no longer current. Younger respondents also employed syntactic variations not found among older adults. For example, a 24-year old male from Glen Carbon, IL (within the dialect island), was more likely to use 
whenever than when, even for events that were unique and whose date or time was known. On the eastern fringes of the island, a 24-year old female from Highland, IL, used the same form. The use of whenever where other dialects use when was accepted by $16 \%$ of our respondents. Older respondents found these usages as unusual.

Other age-related variations were found in the positive use of anymore for what is elsewhere a negative polarity item, for example, in the use of "Gas is so expensive anymore, I hardly ever fill my tank." About 26\% of younger respondents accepted this usage. A 22-year old male from Staunton, IL, and a 24-year old male from Sullivan, IL (both outside the Metro East) reported regularly using this form, and also deleted the complement of prepositions with interrogatives such as, "Are you coming with?" while including final particles in sentences such as "Where are you at?" The use of particle at, though, was far more common than the complement deletion after the preposition with $50 \%$ and $27 \%$ acceptance of these forms, respectively).

\section{DISCUSSION}

We found lexical evidence for a dialect island in Greater St. Louis, as well as, significant differences within the island. We also uncovered evidence of age differences as well. These results do not substantially differ from previous research on the region, but does expand and add to them. Minor differences exist. For example, Murray claimed that, "Children who intentionally miss school in St. Louis play hooky —a Northern and North Midlands term..." (1993, p. 129). While some of our data confirmed the presence of this term (including appearances within the I-55 Corridor), the survey results do not reveal a statistically significant difference in the use of this term within the St. Louis and County, relative to the rest of Illinois. In fact, there is great homogeneity in the majority responses for most questions, regardless of sociolinguistic factors or location. It is only in a closer examination of variables and differences in predicted probabilities that interesting observations emerge.

Many other examinations of the area have been based on fewer participants or less refined data, so this study contributes to our knowledge base about the region. For example, the HDS (2003) received these responses from Illinois residents regarding its item \#63: 
Table 2: What do you call the drink made with milk and ice cream?

\begin{tabular}{|c|c|c|}
\hline Response Option & Illinois Residents & Missouri Residents \\
\hline Milkshake/Shake & $98.99 \%$ & $99.05 \%$ \\
\hline Frappe & $.47 \%$ & $.15 \%$ \\
\hline Cabinet & $.08 \%$ & $.07 \%$ \\
\hline Velvet & - & $.07 \%$ \\
\hline Thick Shake & $.31 \%$ & - \\
\hline Other & $.16 \%$ & $.66 \%$ \\
\hline
\end{tabular}

Source: Harvard Dialect Study (2003).

The HDS illustrates these percentages by state. Unfortunately, its findings do not analyze the variation that exists within specific cities, states, or regions, much less provide a basis for comparison between parts of Greater St. Louis. What is more, showing percentages by state does not provide explanatory leverage for those interested in cross-state dialect islands. ${ }^{11}$ For instance, the HDS data do not allow us to perform any comparison between parts of Greater St. Louis, while our data allows for this comparison. For example, we find statistically significant differences between the choice of shake and milkshake in the halves of the island, but the HDS conflation of the two terms cannot capture that difference.

Rather than reporting raw percentages of usage, our study provides a picture of predicted probabilities by location or sociolinguistic variables. The advantage of such an approach becomes clear when we notice that it provides a more fine-tuned examination of variables that reveals differences in patterning.

It is, of course, unsurprising that generational differences create opportunities for language variation. It has always been so, but there are reasons to suspect that these changes are accelerating for the greying population of Southern Illinois and Missouri. From 2010-2016, the percentage of Illinois persons 65 years or older has risen from $12.5 \%$ to $14.6 \%$ and in Missouri from $14.0 \%$ to $16.1 \%$, mirroring a growth of this age group in the U.S. more generally (13\% to $15.2 \%)$ during this period (Census Bureau). Still, it is interesting that respondents-younger or older-do not always respond in a fixed way to questions. There are enough distinctions that we can calculate predicted probabilities within a sociological group; however, as we might expect, respondents often alter their lexical choice given the utterance event. 
This was sometimes observed when a respondent would give a majority response in the somewhat formal survey setting, but would make a different choice during a more casual interview. This variability in choices was also observed geographically, where respondents from different areas would have a variety of lexical resources at their disposal and would select from these resources to fit the context or imagined expectations, or to align themselves with a certain dialect for intended purposes.

It is curious that for those lexical items where there were differences between St. Louis and the Metro East region, the differences seemed to distinctively pattern: St. Louis residents displayed stronger preferences for particular lexical choices, while the Metro East respondents tended to display more response variability. Perhaps this difference relates to the point made at the onset of this paper: Illinois is unusual among the states in that it contains a more diverse set of language regions than is found in any other state. That greater diversity may translate into a broader set of acceptable lexical choices.

A more intriguing explanation for this patterning may be found in the distinct identities of the halves of the island. It is commonly said in the Metro East that the bridges to St. Louis only go one direction. Those in the Metro East are far more likely to cross those bridges for work, social events, commerce, and other activities than residents of St. Louis crossing the river to Illinois. Those who claim an urban identity will be more likely to affiliate with St. Louis, with the prestige of the well-known city exercising its influence on lexical choices.

Since the St. Louis "island" and other parts of Southwestern Illinois encompass so many overlapping dialectal influences, it may be that rather than identifying regions of Illinois by a dialectal name, it is more accurate to identify what kind of dialectal resources exist in particular regions. Frazer voiced such a concern when he stated that, "...the use of labels in itself is a problem. When I say 'Midland,' or 'West Midland,' I am certainly using ‘explanatory fictions...'” (2006, p. 206, see also Woodward, 2003). Rather than fixed dialectal regions in Illinois, we have variant language use that draws upon the linguistic resources of the region, contextual factors, and the social variables interacting with the lived reality of language use. The social variable examined here-age-is not the complete picture. A fuller understanding of choices would have to also look at variables such as racial and ethnic identity, 
educational attainment, gender identity, socioeconomic class, and others. Even the geographic indicators raise a question about the usefulness of these idealized boundary constructs, except as a description of possible linguistic resources that speakers possess. In this case, there is both an island and a non-island, depending on how one slices the linguistic data.

The idea that speakers draw upon their linguistic repertoire in different ways for varying purposes is not a new one, although the concept appears to be more fully discussed for some linguistic variables than others. Benors (2010) highlighted the concept of pools of distinctive linguistic resources, recalling Fought's notion of a "pool of resources from which members of a speech community draw the linguistic tools they need" (2006, p. 21). This notion of distinctive repertoires may be particularly useful in an area where so many overlapping linguistic influences have left their mark, while at the same time an area still in transition with new immigrant communities, racial divides, and an aging population.

There are many imagined communities and identities within in the St. Louis dialect island, and we may ultimately need to engage in the enterprise that Benor commends, “... shifting our analytic focus from the language variety to the individual, the group, and distinctive linguistic features," so that we can, “...shed light on the social meaning of language” (2010, p. 177). Such an enterprise could give us a better understanding of shifts occurring due to variation based on social causation (in this case, both age and the broader historic migration patterns influencing present-day Illinois dialects), and contextual resources (influence of current neighboring dialects, family idiolects, micro-variation in communities, and so on).

This kind of inquiry allows for heightened understanding of language behavior in our region, and ultimately provides a better look at the socio-cultural impacts of dialect. A desired impact of such research is that it would provide a basis to discuss divergent attitudes towards speakers of dialectal variations in our communities. Linguistic behavior is often a persistent feature of discriminatory judgments made against those who come from different speech communities, but what we see in this study is that heterogeneity and homogeneity exist in one and the same community. If Labov's (1984) "Cumulative Principle" is right (i.e., "the more you know, the more you can find out"), then perhaps the 
more we can know about our neighbors in a region, the better we can understand them, and hopefully, the more accepting we can become.

\section{FUTURE RESEARCH}

The independent variables that we discuss were limited to age and location; however, these give far less than the complete picture we prefer. Greater efforts are needed to piece together precisely how the various linguistic influences in Illinois and Missouri are involved in the diverse linguistic repertoire of the region. Furthermore, our focus has been primarily on lexicon, but there is still a greater need to identify the interactions between lexicon, phonology, and syntax in the region.

This study would have benefitted from a more robust and racially diverse pool of respondents. This survey involved convenience sampling and did not capture the wide diversity in Greater St. Louis. Further research should see how the region's users of AAVE (especially in the North County region of St. Louis and East St. Louis in the Metro East), and the ethnic dialects, old and new, would enhance our understanding of Greater St. Louis. McClelland (2016) relates his conversations with black men who stated that the stereotypical pronunciations in St. Louis, such as "farty" ("forty") and "worsh" ("wash") belonged to white speech in the area. McClelland further argued that “...Members of the upper class, females, and young informants tend to use Northern and North Midland speech; members of the lower class, males, and elderly informants, however, tend to use Southern and South Midland forms" (2016). Whether this observation can be shown to be true will depend on further investigation and analysis into the linguistic repertoires of Southern Illinois, St. Louis, and the Metro East. We hope that our findings intensify interest in the region and kindle further explorations of its dialects. 


\section{NOTES}

We thank Kristine Hildebrandt and Laura Wehmer-Callahan, who participated heavily in the design and data collection phases of this research. We also thank the numerous Undergraduate Research and Creative Activities (URCA) students from Southern Illinois University Edwardsville (SIUE) who assisted the project, especially Chase Tiffany, who worked extensively on lexical issues. Thanks to Wendy Shaw for her assistance with geographical modeling. Thanks, too, to Grete Graf and Tom Purnell for their helpful comments. Funding for this project was provided in part by an SIUE Seed, Transitional, and Exploratory Projects (STEP) grant.

${ }^{1}$ Although, the Atlas states, "The transitional St. Louis Corridor shows the lowest homogeneity" of these areas).

${ }^{2}$ The exceptions are St. Louis city proper and Carbondale.

${ }^{3}$ Because we have so few nonwhite respndents, it is possible that the results that we report here solely reflect white speech patterns in our sampling region. To explore this possibility, we constrained the data to solely white respondents, and respecified all of the models. The signs and significance patterns are identical to what report here, with a couple of exceptions: the coefficients for "Grocery basket" $(p=.134)$ and "All others for the little points of skin" $(\mathrm{p}=.112)$ for the Missouri Side variable are no longer significant at the $\mathrm{p}<.05$-level. Moreover, the coefficient for the sex variable in the "All others for generic term for blended, semi-frozen, cream, or milk-based drink" model $(\mathrm{p}=.059)$ is no longer significant at the $\mathrm{p}<.05$-level. However, the coefficient for Metro East in the "Two or more for insect that looks like a large thin spider" is now negative and statistically significant at the $p<.05$-level where it was not previously. Finally, the coefficient for the education variable in the "Malt" model $(p=.060)$ is not statistically significant at the $\mathrm{p}<.05$-level. We can say two things about these results: 1 ) there is no systematic pattern to them that undermines any of the conclusions in this piece; and 2) there are relatively few differences in the overall results when we constrain the data to solely whites.

${ }^{4}$ We had no respondents from Franklin, Jefferson, Lincoln, St. Charles, or Warren counties in Missouri. The Census Bureau (2017) considers these counties to be part of the St. Louis metropolitan area.

${ }^{5}$ We used the mlogit package in R to implement these routines (see e.g., Henningsen and Toomet 2011).

${ }^{6} \mathrm{We}$ used 1000 bootstrap replications in the generation of our results.

${ }^{7}$ To compute this change, we generate the baseline probability of a particular response for a respondent who is not from either side of the Mississippi River in Greater St. Louis, is 43 years old, is female, makes between $\$ 51,000$ and $\$ 75,000$ per year, and had some college education. We chose these categories because we wanted to use the modal categories for income, education, and sex. Also, we wanted to select an observation not from either side of the Mississippi River because we wanted to compute the change in predicted probabilities for someone from one of the sides of the Mississippi River.

${ }^{8}$ To compute this change, we began with the baseline probability of a particular response. Then, we compute the probability of a particular response, given a change in the value of one independent variable while holding all others constant. If the independent variable is binary (as with the St. Louis area, Metro East and sex variables), we changed the value for this variable from zero to one while holding all others constant to generate a new predicted probability. If the independent variable is continuous (as with age), then we changed the valye for this variable from the mean (43) to one standard deviation above that value (to 60) while holding all others constant to generate a new predicted probability. Finally, we difference the new predicted probability from the baseline probability to produce the changes in predicted probability which are graphically represented in Figures 1 through 12.

${ }^{9}$ Ideally, these figures would have confidence intervals surrounding the predictions. We used the predict command in $\mathrm{R}$ to generate our predicted probabilities, and these do have standard errors that this command produces. However, there is reason to believe that these standard errors are inaccurate in this application because of the presence of spatial autocorrelation in our data. Consequently, we report the 
predicted probabilities in the series of graphs, but do not graphically illustrate the standard errors. The standard errors for this analysis were produced as part of the process by which cluser-adjusted standard errors were computed. Unfortunately, the computational processes that produced the cluster-adjusted standard errors cannot also be used to produce cluster-adjusted standard errors when computing predicted probabilities.

${ }^{10}$ However, Figures 3 through 6 do not undermine this account, but rather, show differences within the Greater St. Louis area on some measures.

${ }^{11}$ We thank a reviewer for pointing this out to us. 


\section{APPENDIX A: CATEGORIZED RESPONSES TO QUESTION VARIABLES}

Notes: The survey used open-ended questions. The categories listed below show groupings used for data coding.

\section{DEPENDENT VARIABLES}

What do you call the wheeled contraption in which you carry groceries at the market?

1: Shopping Cart; 2: Two or More Things Stated; 3: Cart; 4: Grocery Cart; 5: Grocery Basket; 6: All Others

What generic term would you use for any blended, semi-frozen, cream or milk-based drink?

1: Milkshake; 2: Two or More Things Stated; 3: Shake; 4: Malt; 5: Smoothie; 6: All Others

What do you call the device that provides drinking water with the push of a button, usually found in an office hallway or at a gymnasium?

1: Water Fountain; 2: Two or More Things Stated; 3: Water Cooler; 4: Water Jug; 5: Drinking Fountain or Fountain; 6: All Others

What do you call the little grey creature (looks like an insect) that rolls up into a little ball if you touch it?

1: Pillbug; 2: Two or More Things Stated; 3: Roly Poly; 4: All Others

If you are cold, and little points of skin begin to raise up on your arms or legs, you have

1: Goosebumps; 2: Two or More Things Stated; 3: Goosepimples; 4: All Others

What is the general term that you use for the meal that you eat in the evening?

1: Dinner; 2: Two or More Things Stated; 3: Supper; 4: All Others

What is the insect that looks like a large thin spider and skittles across the surface of the water?

1: Waterbug; 2: Two or More Things Stated; 3: Water Spider; 4: Water Strider; 5: Water Skimmer; 6: Water Skipper; 7: All Others

INDEPENDENT VARIABLES

Location and Language History:

Where were you born/raised (city/town, state and ZIP)?

Is English your first language? If not, what is your first language?

If you ever lived in a different area for more than one year, please list the cities/towns \& states \& the number of years you lived there (includes time in college, overseas and/or in the military): 
Age and Gender:

What are your age and your gender?

Education:

What is the highest degree of education you have received? (or are you in school now?)

These answers were collapsed as follows:

1: Less than High School or Trade School; 2: High School Diploma; 3: In College or Some College ; 4 : Bachelor's Degree; 5: Masters, Ph.D., or other graduate degree.

Income:

Please circle your estimated family annual income (before taxes)

1: $\$ 0-\$ 25,000 ; 2: \$ 26,000-\$ 50,000 ; 3: \$ 51,000-\$ 75,000 ; 4: \$ 76,000-\$ 100,000 ; 5: \$ 101,000$ - higher

APPENDIX B: SUMMARY STATISTICS FOR VARIABLES

\begin{tabular}{|c|c|c|c|c|}
\hline Variable & $\underline{\text { Mean }}$ & $\underline{\text { Standard Deviation }}$ & Minimum & Maximum \\
\hline Wheeled Contraption & 2.89 & 1.15 & 1 & 6 \\
\hline Milk-Based Drink & 2.72 & 1.47 & 1 & 6 \\
\hline Drinking Water Device & 2.52 & 1.92 & 1 & 6 \\
\hline Grey Creature & 2.88 & .82 & 1 & 4 \\
\hline Points of Skin & 1.11 & .50 & 1 & 4 \\
\hline Meal Eaten in the Evening & 2.08 & .99 & 1 & 4 \\
\hline Large, Thin Spider that Skittles & 2.14 & 1.65 & 1 & 7 \\
\hline Age & 43.53 & 16.76 & 14 & 85 \\
\hline Sex & .30 & .46 & 1 & 5 \\
\hline Education & 3.53 & 1.11 & 1 & 5 \\
\hline Income & 3.25 & 1.28 & 0 & 1 \\
\hline Metro East & .67 & .47 & 0 & 1 \\
\hline $\begin{array}{c}\text { St. Louis City and County } \\
\text { "Missouri side" }\end{array}$ & .04 & .19 & & \\
\hline
\end{tabular}




\section{APPENDiX C: MultinOMIAL LOGISTIC REGRESSIONS FOR FiguRES SEVEN THROUGH NiNE}

Notes: The values in each of these tables are the mean coefficient estimates from our multinomial logistic regression. The values in parenthesis are cluster-adjusted bootstrapped p-values. Finally, ${ }^{*}$ denotes $\mathrm{p}<.05$; $* *$ denotes $\mathrm{p}<.01$; and $* * *$ denotes $\mathrm{p}<.01$; all two-tailed tests.

Table One: Wheeled Contraption to Carry Groceries

\begin{tabular}{|c|c|c|c|c|c|}
\hline Independent Variable & Two or More & $\underline{\text { Cart }}$ & Grocery Cart & Grocery Basket & All Others \\
\hline Age & $\begin{array}{c}.004 \\
(.778)\end{array}$ & $\begin{array}{l}-.0004 \\
(.914)\end{array}$ & $\begin{array}{l}-.024 * * * \\
(<.0001)\end{array}$ & $\begin{array}{c}.019 \\
(.172)\end{array}$ & $\begin{array}{l}-.012 \\
(.554)\end{array}$ \\
\hline Gender & $\begin{array}{l}.024 \\
(.977)\end{array}$ & $\begin{array}{c}-.485^{* *} \\
(.001)\end{array}$ & $\begin{array}{l}-.412 \\
(.251)\end{array}$ & $\begin{array}{l}-2.021 \\
(.331)\end{array}$ & $\begin{array}{c}.681 \\
(.256)\end{array}$ \\
\hline Income & $\begin{array}{l}-.306 \\
(.223)\end{array}$ & $\begin{array}{l}-.094 \\
(.450)\end{array}$ & $\begin{array}{l}-.023 \\
(.800)\end{array}$ & $\begin{array}{l}-.088 \\
(.585)\end{array}$ & $\begin{array}{c}.245 \\
(.364)\end{array}$ \\
\hline Education & $\begin{array}{c}.177 \\
(.609)\end{array}$ & $\begin{array}{c}.077 \\
(.386)\end{array}$ & $\begin{array}{l}-.067 \\
(.521)\end{array}$ & $\begin{array}{l}-.152 \\
(.674)\end{array}$ & $\begin{array}{l}.731 * \\
(.042)\end{array}$ \\
\hline St. Louis Region & $\begin{array}{l}-.069 \\
(.917)\end{array}$ & $\begin{array}{l}.489 * \\
(.043)\end{array}$ & $\begin{array}{c}.328 \\
(.266)\end{array}$ & $\begin{array}{c}.549 \\
(.415)\end{array}$ & $\begin{array}{c}.558 \\
(.582)\end{array}$ \\
\hline Intercept & $\begin{array}{l}-2.064 \\
(.092)\end{array}$ & $\begin{array}{c}.722 \\
(.095)\end{array}$ & $\begin{array}{l}0.722 \\
(.154)\end{array}$ & $\begin{array}{l}-2.278 \\
(.093)\end{array}$ & $\begin{array}{l}-6.835 \\
(.212)\end{array}$ \\
\hline $\mathrm{N}$ & \multicolumn{5}{|c|}{588} \\
\hline Log-Likelihood & \multicolumn{5}{|c|}{-709.02} \\
\hline McFadden $\mathrm{R}^{2}$ & \multicolumn{5}{|c|}{.027} \\
\hline Chi-Square Test & \multicolumn{5}{|c|}{39.643} \\
\hline P-Value & \multicolumn{5}{|c|}{.032} \\
\hline
\end{tabular}

Table Two: Generic term for Blended, Semi-Frozen, Cream, or Milk-Based Drink

\begin{tabular}{|c|c|c|c|c|c|}
\hline Independent Variable & Milkshake & $\underline{\text { Two or More }}$ & $\underline{\text { Malt }}$ & $\underline{\text { Smoothie }}$ & All Others \\
\hline Age & $\begin{array}{l}-.003 \\
(.606)\end{array}$ & $\begin{array}{c}.020 \\
(.088)\end{array}$ & $\begin{array}{l}.068 * * \\
(.009)\end{array}$ & $\begin{array}{l}-.039 \\
(.058)\end{array}$ & $\begin{array}{c}.005 \\
(.544)\end{array}$ \\
\hline Gender & $\begin{array}{l}-.063 \\
(.793)\end{array}$ & $\begin{array}{l}-.534 \\
(.321)\end{array}$ & $\begin{array}{c}.185 \\
(.702)\end{array}$ & $\begin{array}{l}-.606 \\
(.124)\end{array}$ & $\begin{array}{l}.783^{*} \\
(.025)\end{array}$ \\
\hline Income & $\begin{array}{c}.192 * * \\
(.001)\end{array}$ & $\begin{array}{c}.006 \\
(.972)\end{array}$ & $\begin{array}{c}.203 \\
(.066)\end{array}$ & $\begin{array}{l}-.261 \\
(.145)\end{array}$ & $\begin{array}{l}-.291 * \\
(.016)\end{array}$ \\
\hline Education & $\begin{array}{c}-.022 \\
(.889) \\
\end{array}$ & $\begin{array}{c}.004 \\
(.983) \\
\end{array}$ & $\begin{array}{l}-.261 * \\
(.026)\end{array}$ & $\begin{array}{c}.062 \\
(.867) \\
\end{array}$ & $\begin{array}{c}-.208 \\
(.116)\end{array}$ \\
\hline St. Louis Region & $\begin{array}{c}-1.062 * \\
(.014) \\
\end{array}$ & $\begin{array}{c}.563 \\
(.232) \\
\end{array}$ & $\begin{array}{c}.793 \\
(.286) \\
\end{array}$ & $\begin{array}{c}-.433 \\
(.311) \\
\end{array}$ & $\begin{array}{r}-.700 \\
(.139) \\
\end{array}$ \\
\hline Intercept & $\begin{array}{l}1.188 \\
(.188)\end{array}$ & $\begin{array}{c}-3.522 \\
(.065)\end{array}$ & $\begin{array}{r}-6.310 \\
(.055)\end{array}$ & $\begin{array}{c}.351 \\
(.766)\end{array}$ & $\begin{array}{c}-.209 \\
(.797)\end{array}$ \\
\hline $\mathrm{N}$ & \multicolumn{5}{|c|}{575} \\
\hline Log-Likelihood & \multicolumn{5}{|c|}{-732.81} \\
\hline McFadden $\mathrm{R}^{2}$ & \multicolumn{5}{|c|}{.062} \\
\hline Chi-Square Test & \multicolumn{5}{|c|}{97.578} \\
\hline P-Value & \multicolumn{5}{|c|}{$<.0001$} \\
\hline
\end{tabular}


Table Three: Device that Provides Drinking Water with the Push of a Button

\begin{tabular}{|c|c|c|c|c|}
\hline$\frac{\text { Independent }}{\underline{\text { Variable }}}$ & Two or More & $\underline{\text { Water Cooler }}$ & $\begin{array}{l}\text { Drinking } \\
\text { Fountain }\end{array}$ & $\underline{\text { All Others }}$ \\
\hline Age & $\begin{array}{l}-.024 \\
(.369)\end{array}$ & $\begin{array}{c}.013 \\
(.572)\end{array}$ & $\begin{array}{l}.025 * * * \\
(<.0001)\end{array}$ & $\begin{array}{c}.025 \\
(.230)\end{array}$ \\
\hline Gender & $\begin{array}{l}-.274 \\
(.769)\end{array}$ & $\begin{array}{c}.455 \\
(.548)\end{array}$ & $\begin{array}{l}-.220 \\
(.303)\end{array}$ & $\begin{array}{l}1.076^{*} \\
(.034)\end{array}$ \\
\hline Income & $\begin{array}{r}.307 \\
(.486) \\
\end{array}$ & $\begin{array}{l}-.171 \\
(.464) \\
\end{array}$ & $\begin{array}{c}.092 \\
(.172) \\
\end{array}$ & $\begin{array}{l}-.283 \\
(.236) \\
\end{array}$ \\
\hline Education & $\begin{array}{l}.321 \\
(.230)\end{array}$ & $\begin{array}{l}.00003 \\
(.517)\end{array}$ & $\begin{array}{c}.071 \\
(1.000)\end{array}$ & $\begin{array}{l}-.017 \\
(.274)\end{array}$ \\
\hline St. Louis Region & $\begin{array}{c}.325 \\
(.700) \\
\end{array}$ & $\begin{array}{l}.465 \\
(.413) \\
\end{array}$ & $\begin{array}{c}.205 \\
(.483) \\
\end{array}$ & $\begin{array}{c}-.691 \\
(.306) \\
\end{array}$ \\
\hline Intercept & $\begin{array}{l}-4.872 \\
(.104) \\
\end{array}$ & $\begin{array}{l}-3.233 \\
(.125) \\
\end{array}$ & $\begin{array}{c}-2.379 * * * \\
(<.0001) \\
\end{array}$ & $\begin{array}{c}-3.847^{*} \\
(.048) \\
\end{array}$ \\
\hline $\mathrm{N}$ & \multicolumn{4}{|c|}{590} \\
\hline Log-Likelihood & \multicolumn{4}{|c|}{-530.09} \\
\hline McFadden $\mathrm{R}^{2}$ & \multicolumn{4}{|c|}{.037} \\
\hline Chi-Square Test & \multicolumn{4}{|c|}{40.781} \\
\hline P-Value & \multicolumn{4}{|c|}{.004} \\
\hline
\end{tabular}

Table Four: Grey Creature that Rolls Up into a Little Ball if Touched

\begin{tabular}{|c|c|c|c|}
\hline$\frac{\text { Independent }}{\text { Variable }}$ & Pillbug & Two or More & All Others \\
\hline Age & $\begin{array}{l}.032 * * * \\
(<.0001)\end{array}$ & $\begin{array}{c}.033 \\
(.167)\end{array}$ & $\begin{array}{l}.046^{*} \\
(.025)\end{array}$ \\
\hline Gender & $\begin{array}{l}1.036 * * * \\
(<.0001)\end{array}$ & $\begin{array}{l}-.076 \\
(.909)\end{array}$ & $\begin{array}{l}.735^{*} \\
(.017)\end{array}$ \\
\hline Income & $\begin{array}{l}-.038 \\
(.685)\end{array}$ & $\begin{array}{l}.121 \\
(.649)\end{array}$ & $\begin{array}{c}.163 \\
(.102)\end{array}$ \\
\hline Education & $\begin{array}{c}.084 \\
(.328)\end{array}$ & $\begin{array}{l}-.031 \\
(.916)\end{array}$ & $\begin{array}{l}-.376 \\
(.133)\end{array}$ \\
\hline St. Louis Region & $\begin{array}{l}-.306 \\
(.327) \\
\end{array}$ & $\begin{array}{l}-.179 \\
(.749) \\
\end{array}$ & $\begin{array}{l}-.438 \\
(.220) \\
\end{array}$ \\
\hline Intercept & $\begin{array}{c}-3.410 * * * \\
(<.0001) \\
\end{array}$ & $\begin{array}{c}-.4 .960^{*} \\
(.028) \\
\end{array}$ & $\begin{array}{l}-2.804 \\
(.167) \\
\end{array}$ \\
\hline $\mathrm{N}$ & \multicolumn{3}{|c|}{529} \\
\hline Log-Likelihood & \multicolumn{3}{|c|}{-439.40} \\
\hline McFadden $\mathrm{R}^{2}$ & \multicolumn{3}{|c|}{.070} \\
\hline Chi-Square Test & \multicolumn{3}{|c|}{66.426} \\
\hline P-Value & \multicolumn{3}{|c|}{$<.0001$} \\
\hline
\end{tabular}


Table Five: Little Points of Skin that Begin to Rise on Arms or Legs

\begin{tabular}{|c|c|c|c|}
\hline$\frac{\text { Independent }}{\underline{\text { Variable }}}$ & Two or More & Goosepimples & All Others \\
\hline Age & $\begin{array}{l}-.002 \\
(.965)\end{array}$ & $\begin{array}{l}.064 * * \\
(.005)\end{array}$ & $\begin{array}{l}-.023 \\
(.343)\end{array}$ \\
\hline Gender & $\begin{array}{l}-1.415 \\
(.451)\end{array}$ & $\begin{array}{l}.738 \\
(.236)\end{array}$ & $\begin{array}{l}.588 \\
(.193)\end{array}$ \\
\hline Income & $\begin{array}{r}.342 \\
(.299) \\
\end{array}$ & $\begin{array}{l}.231 \\
(.475) \\
\end{array}$ & $\begin{array}{l}.359 \\
(.415) \\
\end{array}$ \\
\hline Education & $\begin{array}{l}-.128 \\
(.714)\end{array}$ & $\begin{array}{l}.004 \\
(.986)\end{array}$ & $\begin{array}{l}.069 \\
(.830)\end{array}$ \\
\hline St. Louis Region & $\begin{array}{l}-.968 \\
(.291) \\
\end{array}$ & $\begin{array}{l}-.945 \\
(.083)\end{array}$ & $\begin{array}{l}-.351 \\
(.504) \\
\end{array}$ \\
\hline Intercept & $\begin{array}{l}-3.800 \\
(.075) \\
\end{array}$ & $\begin{array}{l}-7.478 \\
(.067) \\
\end{array}$ & $\begin{array}{c}-4.445^{*} \\
(.042) \\
\end{array}$ \\
\hline $\mathrm{N}$ & \multicolumn{3}{|c|}{583} \\
\hline Log-Likelihood & \multicolumn{3}{|c|}{-156.26} \\
\hline McFadden $\mathrm{R}^{2}$ & \multicolumn{3}{|c|}{.083} \\
\hline Chi-Square Test & \multicolumn{3}{|c|}{28.414} \\
\hline P-Value & \multicolumn{3}{|c|}{.019} \\
\hline
\end{tabular}

Table Six: General Term Used for the Meal Eaten in the Evening

\begin{tabular}{|c|c|c|c|}
\hline Independent Variable & Dinner & Two or More & All Others \\
\hline Age & $\begin{array}{l}-.043^{*} \\
(.014)\end{array}$ & $\begin{array}{l}-.007 \\
(.704)\end{array}$ & $\begin{array}{l}-.027 \\
(.114)\end{array}$ \\
\hline Gender & $\begin{array}{c}.103 \\
(.708) \\
\end{array}$ & $\begin{array}{l}-.646 \\
(.430)\end{array}$ & $\begin{array}{c}.748 \\
(.661)\end{array}$ \\
\hline Income & $\begin{array}{r}.059 \\
(.276) \\
\end{array}$ & $\begin{array}{l}-.077 \\
(.827) \\
\end{array}$ & $\begin{array}{l}-.256 \\
(.725) \\
\end{array}$ \\
\hline Education & $\begin{array}{l}.191 * * * \\
(<.0001)\end{array}$ & $\begin{array}{c}.165 \\
(.546)\end{array}$ & $\begin{array}{l}-.454 \\
(.503)\end{array}$ \\
\hline St. Louis Region & $\begin{array}{c}.139 \\
(.710)\end{array}$ & $\begin{array}{c}-1.406 \\
(.135)\end{array}$ & $\begin{array}{c}15.209 * * \\
(.001)\end{array}$ \\
\hline Intercept & $\begin{array}{c}.731 \\
(.303)\end{array}$ & $\begin{array}{r}-2.442 \\
(.072)\end{array}$ & $\begin{array}{c}-16.917 * * * \\
(<.0001)\end{array}$ \\
\hline $\mathrm{N}$ & \multicolumn{3}{|c|}{579} \\
\hline Log-Likelihood & \multicolumn{3}{|c|}{-423.85} \\
\hline McFadden $\mathrm{R}^{2}$ & \multicolumn{3}{|c|}{.076} \\
\hline Chi-Square Test & \multicolumn{3}{|c|}{69.687} \\
\hline P-Value & \multicolumn{3}{|c|}{$<.0001$} \\
\hline
\end{tabular}


Table Seven: Insect that Looks like a Large Thin Spider and Skittles Across the Water Surface

\begin{tabular}{|c|c|c|c|c|c|c|}
\hline$\frac{\text { Independent }}{\underline{\text { Variable }}}$ & Two or More & $\underline{\text { Water Spider }}$ & $\underline{\text { Water Strider }}$ & 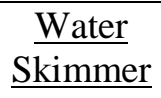 & Water Skipper & $\underline{\text { All Others }}$ \\
\hline Age & $\begin{array}{l}.034 * * * \\
(<.0001) \\
\end{array}$ & $\begin{array}{l}-.005 \\
(.613) \\
\end{array}$ & $\begin{array}{l}-.021 \\
(.091) \\
\end{array}$ & $\begin{array}{l}.030 \\
(.619) \\
\end{array}$ & $\begin{array}{l}-.002 \\
(.696) \\
\end{array}$ & $\begin{array}{l}.011 \\
(.782) \\
\end{array}$ \\
\hline Gender & $\begin{array}{l}.293 \\
(.143)\end{array}$ & $\begin{array}{l}.875^{*} \\
(.016)\end{array}$ & $\begin{array}{l}.615 \\
(.264)\end{array}$ & $\begin{array}{c}-15.149 \\
(.136)\end{array}$ & $\begin{array}{l}.811 * * * \\
(<.0001)\end{array}$ & $\begin{array}{l}-.356 \\
(.663)\end{array}$ \\
\hline Income & $\begin{array}{l}-.009 \\
(.904)\end{array}$ & $\begin{array}{l}.105 \\
(.665)\end{array}$ & $\begin{array}{l}-.103 \\
(.474)\end{array}$ & $\begin{array}{l}-.405 \\
(.109)\end{array}$ & $\begin{array}{l}-.017 \\
(.911)\end{array}$ & $\begin{array}{c}.250 \\
(.290)\end{array}$ \\
\hline Education & $\begin{array}{l}.109^{*} \\
(.026)\end{array}$ & $\begin{array}{l}.324 \\
(.433)\end{array}$ & $\begin{array}{l}.460^{*} \\
(.023)\end{array}$ & $\begin{array}{l}.056 \\
(.894)\end{array}$ & $\begin{array}{l}-.289^{* * *} \\
(.001)\end{array}$ & $\begin{array}{l}-.153 \\
(.785)\end{array}$ \\
\hline St. Louis Region & $\begin{array}{l}-.401 \\
(.073) \\
\end{array}$ & $\begin{array}{l}.024 \\
(.966) \\
\end{array}$ & $\begin{array}{l}1.006 \\
(.240)\end{array}$ & $\begin{array}{l}-.901 \\
(.760)\end{array}$ & $\begin{array}{r}.025 \\
(.938) \\
\end{array}$ & $\begin{array}{r}.328 \\
(.698) \\
\end{array}$ \\
\hline Intercept & $\begin{array}{l}.969^{*} \\
(.024)\end{array}$ & $\begin{array}{c}-3.959 * * \\
(.001) \\
\end{array}$ & $\begin{array}{l}-4.367 \\
(.137) \\
\end{array}$ & $\begin{array}{l}-1.845 \\
(.734) \\
\end{array}$ & $\begin{array}{l}-.621 \\
(.347) \\
\end{array}$ & $\begin{array}{l}-4.316 \\
(.155) \\
\end{array}$ \\
\hline $\mathrm{N}$ & \multicolumn{6}{|c|}{593} \\
\hline Log-Likelihood & \multicolumn{6}{|c|}{-727.63} \\
\hline McFadden $\mathrm{R}^{2}$ & \multicolumn{6}{|c|}{.048} \\
\hline Chi-Square Test & \multicolumn{6}{|c|}{71.615} \\
\hline P-Value & \multicolumn{6}{|c|}{$<.0001$} \\
\hline
\end{tabular}




\section{APPENDIX D: MultinOMIAL LOGISTIC REGRESSIONS FOR FIGURES ONE THROUGH SiX, TEN AND ELEVEN}

Notes: The values in each of these tables are the mean coefficient estimates from our multinomial logistic regression. The values in parenthesis are cluster-adjusted bootstrapped p-values. Finally, $*$ denotes $p<.05$; $* *$ denotes $\mathrm{p}<.01$; and $* * *$ denotes $\mathrm{p}<.01$; all two-tailed tests.

Table One: Wheeled Contraption to Carry Groceries

\begin{tabular}{|c|c|c|c|c|c|}
\hline Independent Variable & $\underline{\text { Two or More }}$ & $\underline{\text { Cart }}$ & $\underline{\text { Grocery Cart }}$ & Grocery Basket & All Others \\
\hline Age & $\begin{array}{c}.004 \\
(.732)\end{array}$ & $\begin{array}{l}-.0002 \\
(.966)\end{array}$ & $\begin{array}{l}.024 * * * * \\
(<.0001)\end{array}$ & $\begin{array}{c}.019 \\
(.184)\end{array}$ & $\begin{array}{l}-.011 \\
(.577)\end{array}$ \\
\hline Sex & $\begin{array}{c}.007 \\
(.993) \\
\end{array}$ & $\begin{array}{l}-.495 * * * \\
(<.0001) \\
\end{array}$ & $\begin{array}{l}-.414 \\
(.244)\end{array}$ & $\begin{array}{l}-2.038 \\
(.338) \\
\end{array}$ & $\begin{array}{c}.678 \\
(.249) \\
\end{array}$ \\
\hline Income & $\begin{array}{l}-.297 \\
(.215)\end{array}$ & $\begin{array}{l}-.089 \\
(.459)\end{array}$ & $\begin{array}{l}-.026 \\
(.734)\end{array}$ & $\begin{array}{l}-.081 \\
(.627)\end{array}$ & $\begin{array}{c}.258 \\
(.325)\end{array}$ \\
\hline Education & $\begin{array}{l}.182 \\
(.586)\end{array}$ & $\begin{array}{l}.080 \\
(.402)\end{array}$ & $\begin{array}{l}-.066 \\
(.503)\end{array}$ & $\begin{array}{l}-.153 \\
(.684)\end{array}$ & $\begin{array}{l}.744 * \\
(.045)\end{array}$ \\
\hline Metro East & $\begin{array}{c}.010 \\
(.990) \\
\end{array}$ & $\begin{array}{l}.538 * \\
(.022)\end{array}$ & $\begin{array}{c}.316 \\
(.290) \\
\end{array}$ & $\begin{array}{c}.633 \\
(.299) \\
\end{array}$ & $\begin{array}{c}.656 \\
(.476) \\
\end{array}$ \\
\hline Missouri Side & $\begin{array}{c}-15.818 * * \\
(.005)\end{array}$ & $\begin{array}{l}-.365 \\
(.058)\end{array}$ & $\begin{array}{c}.445 \\
(.132)\end{array}$ & $\begin{array}{c}-15.495^{*} \\
(.033)\end{array}$ & $\begin{array}{c}-14.848 \\
(.119)\end{array}$ \\
\hline Intercept & $\begin{array}{l}-2.115 \\
(.110) \\
\end{array}$ & $\begin{array}{c}.688 \\
(.094) \\
\end{array}$ & $\begin{array}{l}-.719 \\
(.146) \\
\end{array}$ & $\begin{array}{l}-2.297 \\
(.093) \\
\end{array}$ & $\begin{array}{l}-6.978 \\
(.194) \\
\end{array}$ \\
\hline $\mathrm{N}$ & \multicolumn{5}{|c|}{588} \\
\hline Log-Likelihood & \multicolumn{5}{|c|}{-705.37} \\
\hline McFadden $\mathrm{R}^{2}$ & \multicolumn{5}{|c|}{.032} \\
\hline Chi-Square Test & \multicolumn{5}{|c|}{46.942} \\
\hline P-Value & \multicolumn{5}{|c|}{.025} \\
\hline
\end{tabular}

Table Two: Generic term for Blended, Semi-Frozen, Cream, or Milk-Based Drink

\begin{tabular}{|c|c|c|c|c|c|}
\hline$\underline{\text { Independent Variable }}$ & $\underline{\text { Milkshake }}$ & $\underline{\text { Two or More }}$ & $\underline{\text { Malt }}$ & $\underline{\text { Smoothie }}$ & $\underline{\text { All Others }}$ \\
\hline Age & $\begin{array}{l}-.003 \\
(.620) \\
\end{array}$ & $\begin{array}{c}.020 \\
(.055) \\
\end{array}$ & $\begin{array}{l}.068^{* * *} \\
(.003) \\
\end{array}$ & $\begin{array}{l}-.039 \\
(.053)\end{array}$ & $\begin{array}{c}.004 \\
(.624) \\
\end{array}$ \\
\hline Sex & $\begin{array}{l}-.065 \\
(.784) \\
\end{array}$ & $\begin{array}{l}.533 \\
(.307) \\
\end{array}$ & $\begin{array}{c}.184 \\
(.698) \\
\end{array}$ & $\begin{array}{l}.577 \\
(.088)\end{array}$ & $\begin{array}{l}.816^{*} \\
(.028)\end{array}$ \\
\hline Income & $\begin{array}{l}-.192 * * * \\
(<.0001)\end{array}$ & $\begin{array}{c}.008 \\
(.964)\end{array}$ & $\begin{array}{l}.194 * \\
(.022)\end{array}$ & $\begin{array}{l}-.269 \\
(.143)\end{array}$ & $\begin{array}{c}.310 * * \\
(.002)\end{array}$ \\
\hline Education & $\begin{array}{c}-.022 \\
(.894) \\
\end{array}$ & $\begin{array}{c}.003 \\
(.983) \\
\end{array}$ & $\begin{array}{r}-.260^{*} \\
(.013) \\
\end{array}$ & $\begin{array}{c}.058 \\
(.859) \\
\end{array}$ & $\begin{array}{c}-.217 \\
(.106) \\
\end{array}$ \\
\hline Metro East & $\begin{array}{c}-1.053^{*} \\
(.036) \\
\end{array}$ & $\begin{array}{c}.570 \\
(.231) \\
\end{array}$ & $\begin{array}{c}.758 \\
(.373) \\
\end{array}$ & $\begin{array}{l}-.507 \\
(.176)\end{array}$ & $\begin{array}{l}-.829 \\
(.093)\end{array}$ \\
\hline Missouri Side & $\begin{array}{c}-1.347 * * * \\
(<.0001)\end{array}$ & $\begin{array}{c}.425 \\
(.365) \\
\end{array}$ & $\begin{array}{l}1.274 \\
(.073) \\
\end{array}$ & $\begin{array}{c}.565 \\
(.139) \\
\end{array}$ & $\begin{array}{c}.687 \\
(.003) \\
\end{array}$ \\
\hline Intercept & $\begin{array}{l}1.188 \\
(.174) \\
\end{array}$ & $\begin{array}{l}-3.528 \\
(.066) \\
\end{array}$ & $\begin{array}{c}-6.269 * \\
(.050) \\
\end{array}$ & $\begin{array}{c}.395 \\
(.718) \\
\end{array}$ & $\begin{array}{c}-.089 \\
(.927) \\
\end{array}$ \\
\hline $\mathrm{N}$ & \multicolumn{5}{|c|}{575} \\
\hline Log-Likelihood & \multicolumn{5}{|c|}{-729.46} \\
\hline McFadden $\mathrm{R}^{2}$ & \multicolumn{5}{|c|}{.067} \\
\hline Chi-Square Test & \multicolumn{5}{|c|}{104.29} \\
\hline P-Value & \multicolumn{5}{|c|}{$<.0001$} \\
\hline
\end{tabular}


Table Three: Device that Provides Drinking Water with the Push of a Button

\begin{tabular}{|c|c|c|c|c|c|}
\hline$\frac{\text { Independent }}{\text { Variable }}$ & $\underline{\text { Two or More }}$ & $\underline{\text { Water Cooler }}$ & Water Jug & $\begin{array}{l}\text { Drinking } \\
\text { Fountain }\end{array}$ & All Others \\
\hline Age & $\begin{array}{l}-.024 \\
(.366)\end{array}$ & $\begin{array}{c}.008 \\
(.692)\end{array}$ & $\begin{array}{c}.194 \\
(.408)\end{array}$ & $\begin{array}{l}.026 * * * \\
(<.0001)\end{array}$ & $\begin{array}{c}.012 \\
(.449)\end{array}$ \\
\hline Sex & $\begin{array}{l}-.279 \\
(.757)\end{array}$ & $\begin{array}{l}.517 \\
(.488)\end{array}$ & $\begin{array}{c}-18.651 \\
(.336)\end{array}$ & $\begin{array}{l}-.208 \\
(.280)\end{array}$ & $\begin{array}{l}.560 \\
(.233)\end{array}$ \\
\hline Income & $\begin{array}{l}.308 \\
(.493)\end{array}$ & $\begin{array}{l}-.173 \\
(.459)\end{array}$ & $\begin{array}{l}1.173 \\
(.424)\end{array}$ & $\begin{array}{c}.079 \\
(.161)\end{array}$ & $\begin{array}{l}-.074 \\
(.704)\end{array}$ \\
\hline Education & $\begin{array}{l}.325 \\
(.509) \\
\end{array}$ & $\begin{array}{c}.072 \\
(.755)\end{array}$ & $\begin{array}{l}-4.812 \\
(.384) \\
\end{array}$ & $\begin{array}{l}.069 \\
(.221) \\
\end{array}$ & $\begin{array}{c}.261 \\
(.404)\end{array}$ \\
\hline Metro East & $\begin{array}{c}.346 \\
(.705)\end{array}$ & $\begin{array}{c}.457 \\
(.424)\end{array}$ & $\begin{array}{l}1.246 \\
(.326)\end{array}$ & $\begin{array}{c}.090 \\
(.767)\end{array}$ & $\begin{array}{l}-.604 \\
(.138)\end{array}$ \\
\hline Missouri Side & $\begin{array}{c}-17.824 \\
(.062)\end{array}$ & $\begin{array}{c}-18.479 * * \\
(.008)\end{array}$ & $\begin{array}{l}-3.388 \\
(.321)\end{array}$ & $\begin{array}{c}2.160 * * * \\
(<.0001)\end{array}$ & $\begin{array}{l}1.409 * * * \\
(<.0001)\end{array}$ \\
\hline Intercept & $\begin{array}{l}-4.880 \\
(.111)\end{array}$ & $\begin{array}{l}-3.113 \\
(.141)\end{array}$ & $\begin{array}{c}-2.179 * * \\
(.005)\end{array}$ & $\begin{array}{c}-2.338 * * * \\
(<.0001)\end{array}$ & $\begin{array}{l}-4.211 \\
(.007)\end{array}$ \\
\hline $\mathrm{N}$ & \multicolumn{5}{|c|}{590} \\
\hline Log-Likelihood & \multicolumn{5}{|c|}{-547.86} \\
\hline McFadden $\mathrm{R}^{2}$ & \multicolumn{5}{|c|}{.058} \\
\hline Chi-Square Test & \multicolumn{5}{|c|}{67.608} \\
\hline P-Value & \multicolumn{5}{|c|}{.0001} \\
\hline
\end{tabular}

Table Four: Grey Creature that Rolls Up into a Little Ball if Touched

\begin{tabular}{|c|c|c|c|}
\hline$\frac{\text { Independent }}{\text { Variable }}$ & Pillbug & Two or More & All Others \\
\hline Age & $\begin{array}{l}.032 * * * \\
(<.0001) \\
\end{array}$ & $\begin{array}{c}.033 \\
(.148) \\
\end{array}$ & $\begin{array}{l}.046^{*} \\
(.029) \\
\end{array}$ \\
\hline Sex & $\begin{array}{l}1.040 * * * \\
(<.0001)\end{array}$ & $\begin{array}{l}-.081 \\
(.898)\end{array}$ & $\begin{array}{l}.734 * \\
(.011)\end{array}$ \\
\hline Income & $\begin{array}{l}-.022 \\
(.804)\end{array}$ & $\begin{array}{c}.112 \\
(.663)\end{array}$ & $\begin{array}{c}.170 \\
(.092)\end{array}$ \\
\hline Education & $\begin{array}{c}.094 \\
(.307)\end{array}$ & $\begin{array}{l}-.030 \\
(.924)\end{array}$ & $\begin{array}{l}-.373 \\
(.136)\end{array}$ \\
\hline Metro East & $\begin{array}{l}-.222 \\
(.498)\end{array}$ & $\begin{array}{l}-.218 \\
(.700)\end{array}$ & $\begin{array}{l}-.395 \\
(.313)\end{array}$ \\
\hline Missouri Side & $\begin{array}{c}-16.882^{* * * *} \\
(<.0001)\end{array}$ & $\begin{array}{c}.157 \\
(.801)\end{array}$ & $\begin{array}{c}-1.164 * * \\
(.002)\end{array}$ \\
\hline Intercept & $\begin{array}{c}-3.526 * * * \\
(<.0001)\end{array}$ & $\begin{array}{c}-4.922 * * * \\
(.015)\end{array}$ & $\begin{array}{l}-2.855 \\
(.153)\end{array}$ \\
\hline $\mathrm{N}$ & \multicolumn{3}{|c|}{529} \\
\hline Log-Likelihood & \multicolumn{3}{|c|}{-435.72} \\
\hline McFadden $\mathrm{R}^{2}$ & \multicolumn{3}{|c|}{.078} \\
\hline Chi-Square Test & \multicolumn{3}{|c|}{73.800} \\
\hline P-Value & \multicolumn{3}{|c|}{$<.0001$} \\
\hline
\end{tabular}


Table Five: Little Points of Skin that Begin to Rise on Arms or Legs

\begin{tabular}{|c|c|c|c|}
\hline$\frac{\text { Independent }}{\underline{\text { Variable }}}$ & $\underline{\text { Two or More }}$ & Goosepimples & $\underline{\text { All Others }}$ \\
\hline Age & $\begin{array}{l}-.001 \\
(.957)\end{array}$ & $\begin{array}{l}.064 * * \\
(.005)\end{array}$ & $\begin{array}{l}-.022 \\
(.347)\end{array}$ \\
\hline Sex & $\begin{array}{r}-1.420 \\
(.455)\end{array}$ & $\begin{array}{l}.256 \\
(.749)\end{array}$ & $\begin{array}{c}.579 \\
(.204)\end{array}$ \\
\hline Income & $\begin{array}{c}.347 \\
(.283)\end{array}$ & $\begin{array}{l}.244 \\
(.450)\end{array}$ & $\begin{array}{c}.366 \\
(.423)\end{array}$ \\
\hline Education & $\begin{array}{l}-.125 \\
(.727) \\
\end{array}$ & $\begin{array}{c}.002 \\
(.997) \\
\end{array}$ & $\begin{array}{c}.076 \\
(.809) \\
\end{array}$ \\
\hline Metro East & $\begin{array}{l}-.903 \\
(.318)\end{array}$ & $\begin{array}{l}-.869 \\
(.109)\end{array}$ & $\begin{array}{l}-.290 \\
(.535)\end{array}$ \\
\hline Missouri Side & $\begin{array}{c}-16.704 * \\
(.035)\end{array}$ & $\begin{array}{c}-16.928 * * * \\
(<.0001)\end{array}$ & $\begin{array}{c}-16.340 * * \\
(.006)\end{array}$ \\
\hline Intercept & $\begin{array}{c}-3.838 \\
(.066)\end{array}$ & $\begin{array}{l}-7.532 \\
(.071)\end{array}$ & $\begin{array}{c}-4.526^{*} \\
(.042)\end{array}$ \\
\hline $\mathrm{N}$ & \multicolumn{3}{|c|}{583} \\
\hline Log-Likelihood & \multicolumn{3}{|c|}{-155.06} \\
\hline McFadden $\mathrm{R}^{2}$ & \multicolumn{3}{|c|}{.090} \\
\hline Chi-Square Test & \multicolumn{3}{|c|}{30.818} \\
\hline P-Value & \multicolumn{3}{|c|}{$<.0001$} \\
\hline
\end{tabular}

Table Six: General Term Used for the Meal Eaten in the Evening

\begin{tabular}{|c|c|c|c|}
\hline Independent Variable & Dinner & Two or More & All Others \\
\hline Age & $\begin{array}{c}-.045^{* *} \\
(.009)\end{array}$ & $\begin{array}{l}-.007 \\
(.690)\end{array}$ & $\begin{array}{l}-.027 \\
(.096)\end{array}$ \\
\hline Sex & $\begin{array}{l}.113 \\
(.676)\end{array}$ & $\begin{array}{l}-.645 \\
(.428)\end{array}$ & $\begin{array}{l}.707 \\
(.688)\end{array}$ \\
\hline Income & $\begin{array}{c}.050 \\
(.344) \\
\end{array}$ & $\begin{array}{l}-.078 \\
(.832) \\
\end{array}$ & $\begin{array}{l}-.261 \\
(.735) \\
\end{array}$ \\
\hline Education & $\begin{array}{l}.195 * * * \\
(<.0001) \\
\end{array}$ & $\begin{array}{c}.163 \\
(.551) \\
\end{array}$ & $\begin{array}{l}-.460 \\
(.517) \\
\end{array}$ \\
\hline Metro East & $\begin{array}{c}.054 \\
(.882) \\
\end{array}$ & $\begin{array}{r}-1.386 \\
(.137) \\
\end{array}$ & $\begin{array}{c}15.217 * * * \\
(<.0001)\end{array}$ \\
\hline Missouri Side & $\begin{array}{l}1.752 * * * \\
(<.0001)\end{array}$ & $\begin{array}{c}-17.214 * * * \\
(<.0001)\end{array}$ & $\begin{array}{l}.491 \\
(.341)\end{array}$ \\
\hline Intercept & $\begin{array}{c}.803 \\
(.262) \\
\end{array}$ & $\begin{array}{l}-2.421 \\
(.065) \\
\end{array}$ & $\begin{array}{c}-16.889 * * * \\
(<.0001)\end{array}$ \\
\hline $\mathrm{N}$ & \multicolumn{3}{|c|}{579} \\
\hline Log-Likelihood & \multicolumn{3}{|c|}{-417.65} \\
\hline McFadden $\mathrm{R}^{2}$ & \multicolumn{3}{|c|}{.089} \\
\hline Chi-Square Test & \multicolumn{3}{|c|}{82.079} \\
\hline P-Value & \multicolumn{3}{|c|}{$<.0001$} \\
\hline
\end{tabular}


Table Seven: Insect that Looks like a Large Thin Spider and Skittles Across the Water Surface

\begin{tabular}{|c|c|c|c|c|c|c|}
\hline$\frac{\text { Independent }}{\text { Variable }}$ & $\underline{\text { Two or More }}$ & $\underline{\text { Water Spider }}$ & $\underline{\text { Water Strider }}$ & 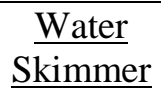 & Water Skipper & All Others \\
\hline Age & $\begin{array}{l}.035 * * * \\
(<.0001) \\
\end{array}$ & $\begin{array}{l}-.005 \\
(.587) \\
\end{array}$ & $\begin{array}{l}-.021 \\
(.090) \\
\end{array}$ & $\begin{array}{l}.029 \\
(.620) \\
\end{array}$ & $\begin{array}{l}-.002 \\
(.751) \\
\end{array}$ & $\begin{array}{l}.011 \\
(.757) \\
\end{array}$ \\
\hline Sex & $\begin{array}{c}.298 \\
(.088)\end{array}$ & $\begin{array}{l}.874 * \\
(.018)\end{array}$ & $\begin{array}{l}.613 \\
(.272)\end{array}$ & $\begin{array}{c}-15.161 \\
(.124)\end{array}$ & $\begin{array}{l}.804 * * * \\
(<.0001)\end{array}$ & $\begin{array}{l}-.355 \\
(.652)\end{array}$ \\
\hline Income & $\begin{array}{l}-.010 \\
(.885) \\
\end{array}$ & $\begin{array}{l}.097 \\
(.641)\end{array}$ & $\begin{array}{l}-.092 \\
(.526) \\
\end{array}$ & $\begin{array}{l}-.403 \\
(.123) \\
\end{array}$ & $\begin{array}{l}-.013 \\
(.939) \\
\end{array}$ & $\begin{array}{l}.260 \\
(.276) \\
\end{array}$ \\
\hline Education & $\begin{array}{l}.108^{*} \\
(.025)\end{array}$ & $\begin{array}{l}.322 \\
(.445)\end{array}$ & $\begin{array}{c}.463 * * * \\
(.025)\end{array}$ & $\begin{array}{l}.049 \\
(.912)\end{array}$ & $\begin{array}{l}-.289^{* * *} \\
(.002)\end{array}$ & $\begin{array}{l}-.155 \\
(.764)\end{array}$ \\
\hline Metro East & $\begin{array}{l}-.419 \\
(.056) \\
\end{array}$ & $\begin{array}{l}-.024 \\
(.966) \\
\end{array}$ & $\begin{array}{l}1.061 \\
(.220)\end{array}$ & $\begin{array}{l}-.849 \\
(.778) \\
\end{array}$ & $\begin{array}{r}.057 \\
(.885) \\
\end{array}$ & $\begin{array}{l}.391 \\
(.605)\end{array}$ \\
\hline Missouri Side & $\begin{array}{l}-.128 \\
(.423) \\
\end{array}$ & $\begin{array}{r}.569 \\
(.112) \\
\end{array}$ & $\begin{array}{c}-16.761 \\
(.095) \\
\end{array}$ & $\begin{array}{c}-16.027 \\
(.341) \\
\end{array}$ & $\begin{array}{c}-.884 * * \\
(.004) \\
\end{array}$ & $\begin{array}{c}-17.082 \\
(.112) \\
\end{array}$ \\
\hline Intercept & $\begin{array}{l}.980^{*} \\
(.014)\end{array}$ & $\begin{array}{c}-3.905 * * * \\
(<.0001)\end{array}$ & $\begin{array}{l}-4.432 \\
(.113)\end{array}$ & $\begin{array}{l}-1.821 \\
(.721)\end{array}$ & $\begin{array}{l}-.649 \\
(.332)\end{array}$ & $\begin{array}{l}-4.370 \\
(.126)\end{array}$ \\
\hline $\mathrm{N}$ & \multicolumn{6}{|c|}{593} \\
\hline Log-Likelihood & \multicolumn{6}{|c|}{-725.27} \\
\hline McFadden $\mathrm{R}^{2}$ & \multicolumn{6}{|c|}{.051} \\
\hline Chi-Square Test & \multicolumn{6}{|c|}{77.334} \\
\hline P-Value & \multicolumn{6}{|c|}{$<.0001$} \\
\hline
\end{tabular}




\section{REFERENCES}

Alim, H. Samy, John Rickford, and Arnetha Ball, eds. 2016. Raciolinguistics: How Language Shapes Our Ideas About Race. Oxford: Oxford University Press.

Auer, Peter, Frans Hinskens, and Paul Kerswill, eds. 2005. Dialect change: Convergence and divergence in European languages. Cambridge: Cambridge University Press.

Benor Sarah Bunin. 2010. "Ethnolinguistic Repertoire: Shifting the Analytic Focus in Language and Ethnicity.” Journal of Sociolinguistics 14.2: 159-83. doi.org/10.1111/j.14679841.2010.00440.x.

Benson, Erica J. 2003. "Folk Linguistic Perceptions and the Mapping of Dialect Boundaries." American Speech 78.3: 307-330.

Bigham, Douglas S. 2008. "Dialect Contact and Accommodation Among Emerging Adults in a University Setting." PhD diss., University of Texas Austin.

Callary, Robert. 1975. "Phonological Change and the Development of an Urban Dialect in Illinois." Language in Society. 4: 155-69. doi.org/10.1017/S0047404500004620.

Cameron, A. Colin and Douglas L. Miller 2015. “A Practitioner's Guide to Cluster-Robust Inference.” The Journal of Human Resources 50.2: 317-372. doi.org/10.3368/jhr.50.2.317.

Carver, Charles. 1989. American Regional Dialects: A Word Geography. Ann Arbor: University of Michigan Press.

DARE. Dictionary of American Regional English. 1985-2013. Edited by Frederic G. Cassidy and Joan Houston Hall. 6 vols. Cambridge: Belknap Press of Harvard University Press.

Esarey, Justin and Andrew Menger 2018. "Practical and Effective Approaches to Dealing with Clustered Data." Forthcoming in Political Science Research and Methods. Available at doi.org/10.1017/psrm.2017.42.

Fenno, Charles R. 1983. "Nineteenth-Century Illinois Dialect: Robert Casey.” American Speech 58.3: 244-253.

Fought, Carmen. 2006. Language and Ethnicity. Cambridge.: Cambridge University Press. 
Frazer, Timothy C. 1978. "South Midland Pronunciation in the North Central States." American Speech 53.40-48. 1987. Midland Illinois Dialect Patterns. American Dialect Society Publication 73. Tuscaloosa: University of Alabama Press. 1993. Heartland English: Variation and Transition in the American Midwest. Tuscaloosa: University of Alabama Press. . 2006. "Midland(s) Dialect Geography; Social and Demographic Variables," in Language Variation and Change in the American Midland; A New Look at 'Heartland' English, edited by Thomas E. Murray and Beth Lee Simon, 199-207. Amsterdam: John Benjamins.

Friedman, Lauren A. 2015. "A Convergence of Dialects in the St. Louis Corridor," University of Pennsylvania Working Papers in Linguistics: 21.2: Article 8.

Henningsen, Arne and Ott Toomet 2011. "MaxLik: A Package for Maximum Likelihood Estimation in R.” Computational Statistics 26.3: 443-458. doi.org/10.1007/s00180-010-0217-1.

Kurath, Hans. 1972. Studies in Area Linguistics. Bloomington: Indiana University Press.

Labov, William. 1984. "Field Methods of the Project in Linguistic Change and Variation." In Language in Use, edited by John Baugh and Joel Sherzer, 28-53. Upper Saddle River: Prentice-Hall. . 2007. “Transmission and Diffusion.” Language 83.2: 344-387. doi.org/10.1353/lan.2007.0082.

Labov, William, Sherry Ash, and Charles Boberg. 1997. "A National Map of the Regional Dialects of American English.” Unpublished manuscript. Philadelphia: University of Pennsylvania. . 1997. “The Midland: North and South.” Map. TESLUR Project. Retrieved August 20, 2017. http://www.ling.upenn.edu/phono_atlas/home.html\#regional. . 2006. Atlas of North American English: Phonetics, Phonology, and Sound Change. New York: Mouton de Gruyter.

Marckwardt, Albert H. 1957. "Principle and Subsidiary Dialect Areas in the North-Central States." Publication of the American Dialect Society. 27.3: 3-15. 
Mattheier, Klaus J. and Werner Besch, eds. 1985. Ortssprachenforschung. Berlin: Schmidt.

Mcclelland, Edward. "The St. Louis Accent: An Explainer.” The Atlantic Monthly Group, City Lab. Last modified November 15, 2016. https://www.citylab.com.

Murray, Thomas E. 1993. "The Language of St. Louis, Missouri: Dialect Mixture in the Urban Midwest." In Heartland English: Variation and Transition in the American Midwest, edited by Timothy Frazer, 125-136. Tuscaloosa: University of Alabama Press. 2002. "Language Variation and Change in the Urban Midwest: The Case of St. Louis, Missouri." Language Variation and Change 14:347-361. doi.org/10.1017/S0954394502143043. 2006. Spirited Speech (St. Louis, MO), in American Voices: How Dialects Differ from Coast to Coast, ed. By Walt Wolfram and Ben Ward. Malden: Blackwell Publishing.

Riehl, Claudia Maria. 2010. "Discontinuous language spaces (Sprachinseln).” In Language and Space: An International Handbook of Linguistic Variation. Volume 1: Theories and Methods, edited by Peter Auer and Jürgen Erich Schmidt, 332-354. Berlin: De Gruter Mouton.

Rosenberg, Peter. 2005. "Dialect convergence in the German language islands (Sprachinseln)" in Dialect change: Convergence and divergence in European languages. Edited by Auer, Peter, Frans Hinskens, and Paul Kerswill, 221-235. Cambridge: Cambridge University Press.

Preston, Dennis R. 2003. “Where are the Dialects of American English at Anyhow?” American Speech 78.3: $235-254$.

State Eats. 2015. “T-Rav is all the rage: Toasted Ravioli-Missouri.” Highlighting Food From Our 50 States. Accessed August 22, 2017. https://stateeats.com/2015/06/12/toasted-ravioli-missouri/.

U.S. Census Bureau. “Population estimates July 1 2016.” Accessed August 20, 2017. https://www.census.gov/quickfacts/.

. "Metropolitan Areas: Concepts, Components, and Population.” Accessed August 25, 2017. https://www.census.gov/prod/2/gen/96statab/app2.pdf.

Vaux, Bert and Scott A. Golder. 2003. Harvard Dialect Survey. 2003. Accessed August 9, 2017. http://dialect.redlog.net/. 
Wolfram, Walt and Natalie Schilling. 2016. American English: Dialects and Variation. Malden.: Wiley Blackwell.

Woodward, James. 2003. Making things happen: A theory of causal explanation. Oxford: Oxford University Press.

Zanuttini, Raffaella, 2014. "North American English: Exploring the Syntactic Frontier," in Microsyntactic Variation in North American English, edited by Raffaella Zanuttini and Laurence Horn, 1-28. Oxford: Oxford University Press.

\section{Author Bios}

Larry L. LaFond is Professor of English Language and Literature at Southern Illinois University Edwardsville. His work has appeared in Kairos, Language Awareness, Language Policy, and Die Unterrichtspraxis, among others, and in edited volumes from Cascadilla, John Benjamins, Kluwer Presses. His research interests include second language acquisition theory and pedagogy, and American dialects.

Kenneth W. Moffett is Professor of Political Science at Southern Illinois University Edwardsville. He is coauthor of Web 2.0 and the Political Mobilization of College Students, and his work has appeared in American Politics Research, Climatic Change, Environment and Behavior, Journal of Information Technology and Politics, Legislative Studies Quarterly, and Social Science Computer Review, and more. His research interests lie primarily in American culture, politics and policy. 